\title{
Memorial $^{1}$
}

Marcia de Vasconcelos Contins Gonçalves

\section{Minha Formação}

Meu interesse pela antropologia teve início quando ingressei no curso de Ciências Sociais no IFCS da UFRJ, no começo da década de 1970, mais especificamente no ano de 1971. Mas posso acrescentar que, muito antes, já me despertavam forte interesse as relações com o outro, o distante, a discussão da alteridade. Esse interesse veio encontrar ressonância nos cursos que frequentei dos meus professores de antropologia do IFCS.

Nasci na cidade do Rio de Janeiro no ano de 1949. Em seguida, morei durante onze anos com minha família em São Paulo, capital. Durante a minha infância, ainda antes de nos mudarmos para São Paulo em 1959, fomos viver em Miami Flórida, Estados Unidos, entre os anos de 1956 e 1958. Meu pai era aviador da Real Transportes Aéreos e fazia a rota internacional Rio de Janeiro, Miami e Chicago.

Esses anos nos Estados Unidos, quando criança, foram anos que precederam as leis de ações afirmativas e os movimentos dos direitos civis e me marcaram muito pessoalmente. Morando em Miami, estudei em uma escola onde não havia, entre os alunos ou professores, nenhum negro. Percebia, através das observações da minha mãe, que nos ônibus regulares da cidade os afro-americanos sentavam-se na parte de trás dos veículos, o que lhe parecia muito estranho. Anos depois, na adolescência e juventude, vim a perceber que no Brasil havia diferentes interpretações sobre o que era ser negro e a forma de lidar com essa questão. Evidentemente, uma forma distinta da norte americana. Não exagero se afirmo que a preocupação intelectual com os estudos comparativos sobre Brasil e Estados Unidos sempre esteve no meu horizonte afetivo e intelectual. Muitos anos depois o universo norte-americano veio a se tornar, para mim, um campo de estudo efetivo, quando frequentei alguns cursos no Graduate Program in Cultural Anthropology na University of Virginia, entre os anos de 1986 e 1989. Esse campo se estendeu quando realizei, nos anos

\footnotetext{
${ }^{1}$ Este memorial foi defendido no dia 26 de fevereiro de 2021. A banca examinadora foi composta pelos Profs. Patrícia Birman (presidente), Heloisa Buarque de Hollanda, Yvonne Maggie, Peter Fry e Maria das Dores Machado.
} 
2000, três pós-doutorados em Universidades norte americanas. Na verdade, nunca abandonei esse interesse intelectual.

Mas outras razões pesaram na minha opção pela antropologia. Ela foi o resultado de um conjunto de circunstâncias positivas ao ingressar no curso de Ciências Sociais do Instituto de Filosofia e Ciências Sociais da UFRJ no ano de 1971. Eu havia chegado recentemente de São Paulo, onde cursara o primeiro e segundo grau, decidindo então fazer faculdade no Rio de Janeiro. Em 1970, em plena ditadura militar, inscrevi-me no pré-vestibular Hélio Alonso no Rio de Janeiro e foi lá que vim a conhecer o Professor Gilberto Velho, que, certo dia, nos concedeu uma excelente palestra sobre a profissão de antropólogo. Acredito que esse foi um momento decisivo em minha escolha profissional. Gilberto Velho era, naquela época, professor de antropologia do IFCS, onde permaneceu até meados dos anos 1970, transferindo-se então para o Programa de Pós-Graduação em Antropologia Social (PPGAS) do Museu Nacional da UFRJ.

Ao ingressar no Curso de Ciências Sociais do IFCS/UFRJ comecei a ter contato sistemático com a antropologia cultural e social, vindo a me interessar principalmente pelos cursos sobre religiões afro brasileiras e relações raciais. Frequentei então cursos conduzidos por alguns professores, cujo trabalho serviu de inspiração para minhas escolhas futuras: os cursos da Professora Yvonne Maggie (que foi minha orientadora de iniciação científica), dos professores Gilberto Velho, Neide Sterci, Jether Ramalho e de outros jovens professores do então Departamento de Ciências Sociais (que nessa época incluía Antropologia, Sociologia e Ciência Política). Esses cursos foram muito importantes para que eu me decidisse a seguir a carreira de pesquisadora nessa área de estudo. Nossos professores de graduação no IFCS eram, na verdade, poucos anos mais velhos do que nós alunos. Foram contratados para substituir aqueles que haviam sido compulsoriamente aposentados pela ditadura militar. Esses jovens professores conseguiram manter uma continuidade intelectual e acadêmica em relação aos antigos mestres e isto fez com que tivéssemos um ótimo curso de graduação. Novas ideias no campo da antropologia emergiam naquele momento. A maneira singular de fazer pesquisa de campo voltada para diversos temas da antropologia e, principalmente, os estudos dos grupos afro brasileiros, que primeiramente me interessaram, centrava-se na ideia implícita de tratar a etnografia não somente como uma metodologia, mas como uma epistemologia. Esse modo de entender a etnografia veio marcar todo o meu trabalho de campo e de pesquisa pelos anos seguintes. 
A convivência com os meus colegas de graduação foi também muito importante para o meu crescimento intelectual e pessoal. Muitos colegas eram militantes políticos, o que era usual nessa época de forte repressão política por parte do Estado brasileiro contra os estudantes e professores. Uma atmosfera de medo e desconfiança era parte do cotidiano de todas as universidades. Eu simpatizava com os movimentos políticos universitários daquela época, apesar de nunca ter cogitado de efetivamente participar de qualquer partido ou organização. O interesse de nós estudantes naquela época dividia-se entre a política e o universo propriamente acadêmico. Foi durante a graduação que fiz ótimas amizades, sendo que muitas duram até hoje. Não somente foi lá que conheci José Reginaldo Gonçalves, em 1971, mas também Sandra de Sá Carneiro, Sandra Camarão, Dina Pinto Sousa, Maria José Carneiro, José Ricardo Ramalho, Michel Misse, Patrícia Monte Mor, Paulo Carneiro e muitos outros. Na casa de minha saudosa amiga Sandra Camarão, em Copacabana, Sandra Carneiro, Reginaldo e eu mantínhamos um grupo de estudo de antropologia, onde líamos e discutíamos as obras de Claude Lévi-Strauss, principalmente. A antropologia era uma forte inspiração. Era uma perspectiva de carreira assim como uma espécie de modo de vida centrado no reconhecimento do outro e na valorização da diversidade. Os excelentes professores com os quais tive a privilégio de estudar no IFCS abriram para mim essa possibilidade de carreira, que então aparecia como muito nova, embora promissora em termos intelectuais e profissionais. Abria-se então para o estudante o horizonte dos cursos de pós-graduação. Para nós da Antropologia, o então PPGAS do Museu Nacional.

Durante o tempo em que fui aluna de graduação, recebi uma bolsa de Iniciação Científica pelo CNPq sob a orientação da Professora Yvonne Maggie. A convivência com ela, nesta época, foi de bolsista, aluna e amiga. Posso dizer que foi com ela que aprendi, além de teoria antropológica, a fazer trabalho de campo. O projeto no qual eu era bolsista versava sobre um terreiro de Umbanda e Candomblé na Baixada Fluminense, Rio de Janeiro. Por essa época, Yvonne já havia terminado sua dissertação de mestrado intitulada "Guerra de Orixá, um estudo de ritual e conflito" 2 , baseada num estudo de caso, focalizando um único terreiro, o que era incomum à época.

A perspectiva de trabalho de campo utilizada por ela, na qual o pesquisador delimita para seus estudos um único contexto de pesquisa, que pode ser

\footnotetext{
${ }^{2}$ Maggie, Yvonne. "Guerra de Orixá: um estudo de ritual e conflito”. Rio de Janeiro, Zahar,2001. 3aed.
} 
posteriormente generalizado para outros contextos, foi determinante para vários outros estudos que vieram a ser realizados na antropologia brasileira, inclusive por mim mesma, quando realizei minha dissertação de mestrado. A qualidade ética e profissional que vim a aprender com a minha orientadora durante a pesquisa no terreiro "Ilê de Oxalá e Obaluaê" da Baixada Fluminense no final da década de 1970, seus ensinamentos de campo com participação intensiva foram para mim uma espécie de iniciação existencial e metodológica na antropologia. Dessa pesquisa resultou um artigo que escrevemos em conjunto no ano de $1980^{3}$. Devo acrescentar que, muitos anos depois desta minha primeira experiência de campo, ainda a levava comigo para outros contextos de pesquisa.

Concluí a graduação em 1975 e como já havia me formado em Biblioteconomia e Documentação em 1973 na Universidade Santa Úrsula, vim a trabalhar como bibliotecária na Biblioteca do Museu de Arte Moderna do Rio de Janeiro, em seguida na Faculdade de Letras da UFRJ e finalmente na Biblioteca do PPGAS do Museu Nacional. O interessante a assinalar é que consegui frequentar, com interesse, os dois cursos no mesmo período: Ciências Sociais e Biblioteconomia. Na Biblioteca da Letras da UFRJ vim a ter contato com inúmeros livros raros sobre relações raciais e religiões afro brasileiras. Tive a oportunidade de catalogar a "Coleção Edison Carneiro", onde pude ler algumas de suas obras, tais como Religiões Negras, Negros Bantos, O quilombo dos Palmares e Candomblés da Bahia. Outros autores também integravam essa coleção: obras de Nina Rodrigues, tais como $O$ animismo fetichista dos negros bahianos; de Roger Bastide: O Candomblé da Bahia e As religiões africanas no Brasil; assim como os livros de Arthur Ramos, Thales de Oliveira e Oracy Nogueira. Esses autores integravam as bibliografias dos cursos de graduação em antropologia do IFCS.

No ano de 1978, já formada em Ciências Sociais e com uma bolsa de estudos, realizei uma pesquisa com Yvonne Maggie e Patrícia Monte-Mor sobre os objetos rituais retirados pela polícia de terreiros no Rio de Janeiro durante as primeiras décadas do século $\mathrm{XX}$ e posteriormente abrigados no acervo do Museu da Polícia Militar do Rio de Janeiro. À época, estávamos preocupadas em saber como essas práticas religiosas sofriam acusações, sendo associadas, por exemplo, às "práticas de magia negra e cartomancia". Além disso, o projeto

\footnotetext{
${ }^{3}$ Maggie, Yvonne; Contins, Marcia. "Gueto cultural ou a Umbanda como modo de vida: notas sobre uma experiência de campo na Baixada Fluminense”. In. Velho, Gilberto coord. O desafio da cidade: novas perspectivas da antropologia brasileira. Rio de Janeiro, Editora Campus, 1980.p. 77-92.
} 
tinha como objetivo discutir como era pensada a noção de "arte" no contexto cotidiano desses grupos religiosos. Qual seria o status conferido à chamada "Arte Afro-Brasileira"? Foi a partir dessas questões que desenvolvemos uma pesquisa chamada, inicialmente, a "Arte nas Religiões Afro-Brasileiras e sua relação com o Estado".

Para responder a estas questões decidimos analisar a coleção de objetos rituais do acervo do Museu da Academia de Polícia Militar do Rio de Janeiro. Esta coleção era chamada de "Coleção de Magia Negra". Foi a primeira coleção do gênero a ser tombada pelo IPHAN. Era composta por objetos obtidos durante a repressão a terreiros de umbanda e candomblé no Rio de Janeiro na primeira metade do século XX. Outras coleções semelhantes puderam ser localizadas no Instituto Histórico e Geográfico de Alagoas e no Instituto Histórico e Geográfico da Bahia. Realizamos um trabalho de campo com visitas constantes ao Museu da Polícia, classificamos e descrevemos as peças religiosas afro brasileiras numa espécie de catálogo. Esse material tinha sido organizado para o Museu da Polícia pelo próprio diretor do museu daquela época, um detetive da polícia que também era umbandista. Na organização das estantes da coleção notamos que a preocupação fundamental era definir os objetos segundo sua relação com o ritual e não com o local ou origem das peças, como seria de se esperar num procedimento museológico profissional.

Minha participação nesta pesquisa foi essencial para a minha carreira de antropóloga. A experiência de pesquisar objetos em um museu, a relação dessas peças com terreiros semelhantes a outros que conheci ou que eu viria a conhecer posteriormente, o uso de material jornalístico enquanto objeto de análise, tudo isso abriu caminho para o desenvolvimento do meu projeto de mestrado. Atualmente o material da "Coleção Magia Negra" é alvo de vários estudos acadêmicos, sendo também reivindicado pelos movimentos negros e por grupos religiosos afro-brasileiros. Assim, diversos movimentos étnicos e religiosos reivindicam aqueles objetos, que são por eles classificados como "Meu Sagrado". Para esses movimentos, tais objetos deveriam retornar aos seus terreiros de origem ou para algum museu que os tratasse como arte religiosa. É interessante observar, agora passados todos esses anos desde que estudamos esses objetos, a importância que veio a assumir na antropologia os estudos e discussões sobre objetos materiais.

Ainda no final dos anos 1970 e início da década 1980 estive associada, enquanto pesquisadora, ao Instituto de Estudos Religiosos (ISER), onde desenvolvi em conjunto com diversos pesquisadores, sob a supervisão do prof. Rubem César Fernandes, um projeto sobre a Visita do Papa João Paulo II ao 
Morro do Vidigal, no Rio de Janeiro. Nesta pesquisa, observamos de que maneira as diferentes religiões encontradas naquele contexto estavam reagindo à visita do pontífice da Igreja Católica a seu território. Analisamos as reações dos terreiros de Umbanda e Candomblé, que ainda existiam no Vidigal daquela época, e também de algumas Igrejas Pentecostais e Neopentecostais. Esse trabalho de campo foi importante para entrar em contato com outras religiões, que ainda não faziam parte dos meus interesses enquanto pesquisadora. Posteriormente vim a desenvolver, na tese de doutorado, um estudo sobre grupos neopentecostais e católicos carismáticos, sem, no entanto, abandonar o viés comparativo com as religiões afro-brasileiras, especialmente em seu convívio diário no espaço da grande cidade. A presença dos neopentecostais no meio urbano já se destacava naquele momento, manifestando-se em grande número quando contrastados com as religiões afro-brasileiras.

Em 1979 fui aprovada para o mestrado em Antropologia Social do Programa de Pós-Graduação em Ciências Sociais do Museu Nacional, da UFRJ. Entre os anos de 1980 e 1983 frequentei os cursos do PPGAS, com uma bolsa do CNPq. Defendi a dissertação em 1983 sob a orientação do Professor Gilberto Velho. Foram anos muito importantes para minha formação. Fui então aluna dos professores Roberto Da Matta, Anthony Seeger, Rubem César Fernandes, Eduardo Viveiros de Castro e José Sergio Leite Lopes, entre outros. A nossa turma do PPGAS viveu uma época muito produtiva daquele Programa, quando podíamos assistir palestras com diversos pesquisadores estrangeiros e brasileiros, e quando diversos projetos estavam sendo realizados pelo corpo docente. Nesta época fui assistente no Projeto Piauí (financiado pela Inter American Foundation), sob orientação do professor Roberto Da Matta. Outros professores então integrantes daquele Programa forneceram-me referências significativas nos estudos sobre etnicidade, tais como como a Professora Francisca Vieira Keller e a Professora Giralda Seiferth. Muitos colegas daquela época do mestrado eu vim a reencontrar na UERJ anos depois, já como professores e intelectuais importantes em suas respectivas áreas de pesquisa.

Nos seus cursos de Antropologia Urbana, Gilberto Velho desenvolvia discussões teóricas ligadas à chamada Escola de Chicago, especialmente sobre "interacionismo simbólico" assim como sobre as noções de "visões de mundo" e "estilos de vida". Essas perspectivas teóricas foram significativas na elaboração da minha dissertação de mestrado. Os cursos sobre ritual e simbolismo ministrados por Roberto Da Matta, de orientação socialestruturalista, foram também excelentes para a minha formação teórica e na construção de minha pesquisa. Ainda no início da década de 1980, recebemos 
no PPGAS do Museu Nacional e no IFCS da UFRJ a visita do antropólogo Victor Turner, africanista com estudos sobre rituais Ndembu, e de sua mulher Edith Turner, também antropóloga. Foram encontros com conversas e palestras para o corpo docente e discente. Victor Turner e Edith Turner estavam muito interessados em conhecer os rituais ligados às religiões afro brasileiras e, nesta ocasião, tiveram a oportunidade de conhecê-los. Yvonne Maggie e eu os levamos para conhecer terreiros de Umbanda e Candomblé na cidade do Rio de Janeiro. Essa experiência de campo em companhia dos dois foi muito produtiva, tanto para eles conhecerem os rituais afro-brasileiros quanto para nós. Eu tive então a oportunidade de observá-los durante prática de trabalho de campo. Anos mais tarde, em 1984, pude rever a professora Edith Turner (Victor Turner falecera em dezembro 1983) na Universidade da Virginia (UVA), em Charlottesville, Estados Unidos, quando frequentei alguns cursos de doutorado no Department of Anthropology.

Defendi minha dissertação no PPGAS do Museu Nacional em 1983: “O Caso da Pomba Gira: reflexões sobre crime, possessão e identidade feminina". Continuando de certa forma o tema que havia explorado com Yvonne Maggie na graduação, numa ressonância de sua orientação, fiz uso da noção de "drama social" para analisar o material que reuni na pesquisa. As noções de ritual, possessão e pessoa, todas discutidas em cursos do mestrado, foram também decisivas para a análise do material da pesquisa. Na banca de defesa da dissertação, pude contar com a participação e comentários de Yvonne Maggie e do Professor Peter Fry, ao lado evidentemente do meu orientador. A ideia de trabalhar o tema da minha dissertação surgiu quando li, nos jornais da época, sobre o assassinato de um homem na região metropolitana do Rio de Janeiro, crime no qual uma suposta "mãe de santo" estaria envolvida. A escolha teve apoio entusiástico de meu orientador e de Yvonne Maggie. Vim a pesquisar o chamado " Caso da Pomba Gira" a partir de matérias publicadas nas colunas policiais dos jornais da época e da mídia em geral e, não menos importante, a partir da consulta aos autos do processo. O caso que teve muita repercussão e foi amplamente debatido à época. Realizei um pequeno trabalho de campo, com entrevistas, no terreiro de um pai de santo que dera apoio religioso à mãe de santo envolvida no caso. Quando comecei a dissertação, eu já tinha alguma experiência de campo com religiões afro-brasileiras, o que me muito me ajudou na pesquisa. O objetivo inicial era analisar o fenômeno da possessão no âmbito restrito as religiões afro-brasileiras. Através dessa análise, minha intenção era descrever e analisar as diferentes concepções de "pessoa" com que os personagens desse drama operavam. Os sujeitos da pesquisa seriam grupos e 
indivíduos que mantivessem relações de "familiaridade" com aquele universo religioso. No entanto, o projeto adquiriu maior amplitude na medida em que adotei um determinado tipo de tratamento em relação ao material etnográfico, descrevendo o desenrolar de um drama. Neste os atores envolvidos eram não somente aqueles que mantinham relações de familiaridade com aquelas já mencionadas religiões, mas também outros cuja relação definia-se precisamente pelo estranhamento em relação àqueles primeiros.

Vários autores interpretavam as religiões afro-brasileiras como fenômeno de sincretismo religioso, definido como a junção de vários "traços", quais sejam: católicos ou europeus, indígenas e africanos. Procedia-se então a uma hierarquização desses "traços", como bem assinalou Yvonne Maggie (2001). Os traços africanos eram associados a traços primitivos, emocionais, não racionais, enquanto os traços espíritas, porque ocidentais, seriam identificados a traços mais "civilizados". A preocupação expressa nesses trabalhos (Rodrigues, Nina, 1935, 45; Ramos, Arthur, 1962) era com a busca de uma origem, que explicaria a presença de tais "traços" nos rituais praticados no Brasil. Havia concomitantemente a obsessão com o aspecto "africano" da religião, valorizado pelo seu lado "exótico", "distante" e "puro". Haveria então uma hierarquia entre as regiões no Brasil, onde a "influência" "africana" poderia se configurar como mais ou menos "misturada" com outras religiões. Desse modo, se por um lado o Candomblé da Bahia era valorizado pelo seu lado "puro", conservando até a atualidade seus rituais vindos da distante África, ele era, por outro lado, também considerado como o mais "emocional", "primitivo" etc.

A questão da autenticidade era um dos focos dos debates na década de 80 sobre as religiões afro-brasileiras. Os terreiros de candomblé no Brasil eram classificados em função de sua "autenticidade" ou "pureza". Diversos antropólogos repensavam então aquelas análises voltadas para o que chamavam de "pureza nagô", ou seja, terreiros considerados mais puros porque estariam ligados diretamente aos rituais africanos. $\mathrm{O}$ meu trabalho repercutia o horizonte intelectual e de pesquisa daquele momento.

Antes de terminar a dissertação no PPGAS do Museu Nacional eu e Reginaldo já estávamos casados e a nossa primeira filha, Isadora, já tinha nascido. Meu então orientador, Gilberto Velho, extremamente dedicado aos seus orientandos, ligava-se aos sábados pela manhã, para saber se eu já havia concluído os capítulos e quantas páginas ainda faltavam. Minhas filhas gêmeas Renata e Mariana nasceram em 1982. Eu dividia com as recém-nascidas o tempo de trabalho dedicado à dissertação. Foi através da orientação atenciosa 
de Gilberto Velho que pude terminar a dissertação dentro do prazo, além da leitura sempre crítica e sensível de Reginaldo.

Um ano depois da defesa do mestrado, em 1984, Reginaldo fora aceito para fazer o doutorado em antropologia na Universidade da Virgínia, UVa, nos Estados Unidos. Para mim, poderia ser uma boa oportunidade para dar continuidade a minhas pesquisas, elaborando os temas religião e etnicidade a partir de um ponto de vista comparativo com o contexto norte-americano. A ideia era refletir comparativamente sobre as religiões no Brasil, situando-me então em um novo contexto geográfico e acadêmico.

Numa tarde chuvosa do mês de junho de 1984, chegamos a Charlotteville, Virginia, com nossas três filhas, as menores ainda bebês. Charlottesville é uma cidade universitária localizada a duas horas de automóvel de Washington, capital. O casal Heloisa Graham e Lee Graham, amigos da minha mãe, moravam em Madison, localidade próxima a Charlottesville, e foram de uma inestimável generosidade ao hospedarem um casal com três filhas pequenas em sua casa nas primeiras semanas de nossa permanência na cidade.

O começo da nossa estadia em Charlottesville foi complicada. Conseguimos um apartamento de três quartos no campus da Universidade de Virginia, mas teríamos que esperar ainda dois meses para mudarmos definitivamente. Tivemos, assim, que nos hospedar primeiro num hotel próximo ao campus da universidade e, em seguida, no International House, local que era mais adequado aos alunos estrangeiros e solteiros, oferecendo hospedagem temporária. A nossa sorte foi que a esposa do orientador do Reginaldo, Eleonor Crocker, ofereceu-nos sua casa para nos hospedar até irmos definitivamente para o apartamento da Universidade. Foi ótimo ter morado com eles e seus dois filhos adolescentes. Foram muito gentis e aprendemos muito com eles sobre a cidade e a universidade. Sem eles, nossa adaptação e permanência na cidade não teriam sido possíveis. Lembro que estávamos no ano de 1984, antes portanto das facilidades da internet e dos cartões de crédito.

O Departamento de Antropologia da UVa tivera até dezembro de 1983, em seu quadro de professores, Victor Turner, o que representava um foco importante do que então se chamava "antropologia simbólica". Esse Departamento, mesmo com a morte de Victor Turner alguns meses antes de nossa chegada aos Estados Unidos, continuou sendo influenciado pelos seus estudos e sua presença era ainda sensível no cotidiano do dos professores e alunos. Como sabemos, Turner era uma referência nos estudos sobre ritual e veio também a focalizar, já no final de sua vida, temas sobre performance e teatro. Esses temas foram abordados em minhas pesquisas. $\mathrm{O}$ fato de tê-lo 
conhecido antes de nossa viagem aos Estados Unidos e ter intimidade com sua obra foi um forte estímulo a continuar meus estudos na Universidade de Virginia.

Estive ligada ao Departamento de Antropologia da UVa, primeiro acompanhando Reginaldo nos encontros sociais e acadêmicos de professores e alunos, e posteriormente quando realizei alguns cursos de doutorado, com bolsa do CNPq entre os anos de 1987 e 1989.

Naquela época pude conhecer, enquanto aluna de pós-graduação, alguns antropólogos cuja relevância se delineava no meio acadêmico. Participei dos cursos de Roy Wagner, Ellen Contini-Morava, J. David Sapir, J. Christopher Crocker, Peter Metcalf. Tive a oportunidade de participar também de discussões em palestras com Frederick Damon, Ravindra Khare, Jeff Hantman, Richard Handler, Susan Mckinnon, além de Edith Turner, que continuou a integrar o Departamento depois da morte de seu marido. Os cursos conduzidos por Edith Turner, todos realizados em sua casa, foram cruciais para entender o que Victor Turner escrevera sobre os aspectos simbólicos do ritual e sobre drama social. Nesses cursos em sua casa, Edith e nós, alunos e alunas, realizávamos performances sobre os rituais descritos nos livros de Victor Turner: The Forest os Symbols, The Ritual Process, Dramas, Fields and Metaphors e outros.

O Departamento recebia regularmente a visita de antropólogos de outras universidades americanas e de outros países, que realizavam palestras e debates, tais como Mary Douglas, Rodney Needham, Louis Dumont, Marshall Sahlins, entre muitos outros. O Departamento permitia e estimulava que os alunos tivessem contato com todos esses nomes que se destacavam como lideranças importantes naquele rico momento da história da antropologia.

Durante os anos que passamos na Universidade de Virginia, realizei um intenso trabalho de campo junto a um grupo de pentecostais negros que habitavam a vizinhança de Charlottesville. Esse trabalho foi primordial para a realização de minha tese de doutorado, que vim a defender em 1995 no Programa de Pós Graduação em Comunicação e Cultura da Universidade Federal do Rio de Janeiro.

A Universidade de Virginia, como todas as grandes universidades norteamericanas, oferecia condições ideais para seus estudantes, especialmente os de pós-graduação: destaco a existência de notáveis bibliotecas. Posso afirmar que os anos que passei na Universidade de Virginia marcaram fortemente minha formação intelectual e acadêmica. $\mathrm{O}$ trabalho de campo que desenvolvi 
e os cursos que frequentei, enquanto estava no Departamento de Antropologia dessa universidade, marcaram minha vida como antropóloga.

Nos primeiros anos em que estive como aluna da pós-graduação, uma profissional de saúde da UVa, nascida em Cabo Verde, apresentou-me o pastor da Igreja Bible Way (O Caminho da Bíblia), Charles White, e sua esposa Rosetta White. A igreja ficava localizada em Fluvanna County, bem próximo à cidade de Charlottesville, onde morávamos. O pastor White atendia pacientes afroamericanos no Hospital da Universidade da Virginia, que apresentavam alguma doença que, segundo o pastor, não era diagnosticada pela medicina oficial. A congregação dos Bible Way tem a maioria de suas igrejas no Estado da Virginia (Centro e Norte) e em Washington, D.C.. Centralizei meus estudos em sua igreja na Virginia e, através de contatos com seus integrantes, pude participar de eventos religiosos em outras igrejas pertencentes à mesma congregação.

Estabeleci um segundo contato com o pastor Charles White, dessa vez em sua casa. Ele e sua esposa Rosetta White podem ser sociologicamente descritos como pertencentes à classe media negra norte-americana. Residiam numa casa relativamente afastada de Charlottesville, a uns vinte minutos de automóvel, e próxima a Monticello, onde está localizada a casa que foi construída por Thomas Jefferson e que foi sua residência (atualmente um monumento histórico nacional e ponto turístico). A casa do pastor era espaçosa e elegante, com um extenso terreno ao seu redor, diferentemente do que eu imaginava para um pastor negro, que, além de pastor, era pintor de paredes, dono de uma pequena firma que prestava serviços de pintura e jatos de areia. Ficava situada num bairro de classe média alta, com predominância de pessoas brancas. Moravam nessa casa o casal White, duas netas de Rosetta e o filho de ambos, Stevie. Rosetta já fora casada e tinha duas filhas e dois filhos desse seu primeiro matrimônio. A maneira como fomos recebidos por eles, em sua casa, foi bastante diferente da relação que mantínhamos com as outras pessoas da cidade e da universidade. Em geral conhecíamos mais famílias brancas e com algumas delas mantínhamos uma relação de amizade. No entanto, o estilo de vida do pastor e de outros negros que viemos a conhecer diferenciava-se muito dos brancos. Em sua casa fomos recebidos de modo extremamente gentil e atencioso. Diferentemente do primeiro dia que o conhecemos, o pastor vestia dessa vez uma roupa de trabalho, suja de tintas. Quando o encontrei da primeira vez, ele vestia terno escuro, gravata, bastante formal, como costumava usar durante os "serviços" de domingo em sua igreja. A relação com eles era fluente e logo ficávamos à vontade. Nunca era sugerido que a visita fosse 
encerrada, seja porque fosse tarde ou por qualquer outra razão, o que era comum quando éramos convidados à casa de nossos amigos americanos brancos.

Aparentemente, o fato de sermos brasileiros facilitava nossa aceitação. $\mathrm{O}$ próprio pastor me contou que ele já havia sido entrevistado por uma antropóloga branca americana, e que respondera suas perguntas de maneira bem formal, uma vez que a comunicação entre eles não teria fluído com facilidade. O que não veio a acontecer na interação comigo e com a minha família. Percorri várias igrejas pentecostais com eles em diversos locais no Estado da Virginia, e também na capital do país, Washington. Quando os estava acompanhando nessas viagens, eu tinha muito acesso a outras igrejas. Meu tempo de pesquisa e trabalho de campo com os pentecostais durou aproximadamente quatro anos, o tempo que permaneci na Universidade da Virginia como aluna e pesquisadora.

Esse grupo de pessoas com as quais vim a interagir para o trabalho de campo entre as igrejas neopentecostais de negros norte-americanos integra a lista daqueles que, significativamente, mediaram nossa percepção e nosso entendimento da sociedade norte-americana. Junto com os professores do Departamento de Antropologia da UVA, eles tiveram papel importante na minha formação como etnógrafa, mostrando-me o quanto o trabalho intelectual e acadêmico depende de extensas redes sociais de solidariedade.

Na época em que retornei ao Brasil em 1989, poucos eram os estudos comparativos sobre Brasil e Estados Unidos dedicados ao tema da religião e baseados em trabalho de campo e observação participante. No Rio de Janeiro, procurei um Programa de Pós-Graduação para continuar o doutorado que havia iniciado nos Estados Unidos. Não pretendia fazer um paralelo histórico ou analítico sobre o protestantismo e o pentecostalismo no Brasil e nos Estados Unidos. Alguns autores já o haviam feito e não seria essa a minha contribuição, mas sim falar da importância destas religiões do ponto de vista do cotidiano de segmentos da população negra da Virginia e do Rio de Janeiro. Com base no trabalho de campo que eu fizera entre os Bible Way, pretendia continuar meus estudos no Brasil para uma análise comparativa com os pentecostais negros no Brasil.

Ao fazer uso da história do pentecostalismo, meu objetivo não era evidentemente a busca da origem e das raízes das diferenças e das semelhanças dos negros nesses dois contextos sociais, mas perceber o papel dessa história no processo presente de construção da auto-identificação de um grupo étnico associado ao pentecostalismo. Por outro lado, a comparação se impunha 
enquanto um método de trabalho bastante útil para iluminar dimensões de determinadas situações sociais presentes, que permaneceriam ocultas se não submetidas a um contraste sistemático com situações diversas.

No contexto institucional do Programa de Pós Graduação em Comunicação e Cultura da ECO/ UFRJ pude reunir naquela ocasião toda a minha experiência acadêmica e de pesquisa dos anos anteriores. Entre os anos de 1991 e 1995, fui muito bem recebida pelo grupo de professores daquela instituição e em especial pela minha orientadora, Professora Heloisa Buarque de Hollanda. Nesta época, além de frequentar cursos na ECO, dei andamento a meu trabalho de campo junto a igrejas neopentecostais do Rio de Janeiro.

A partir do trabalho de campo e das discussões suscitadas pelos cursos de doutorado, comecei a definir de modo mais claro o objetivo da minha tese: a comparação dos modos como são percebidas as práticas e representações pentecostais no Brasil e nos Estados Unidos. O propósito era focalizar situações e experiências sociais e religiosas que iriam servir como ponto de partida para discutir as relações entre brancos e negros nesses dois contextos nacionais. Essas situações e experiências iriam também contribuir para redefinir os usos da comparação nos estudos sobre religião e relações raciais nesses dois contextos.

Os cursos que frequentei foram especialmente relevantes para os debates sobre pós modernidade, muito presentes no final dos anos 1980 e nas primeiras décadas de 1990. Essas discussões, no âmbito dos estudos da religião e etnicidade, foram cruciais para o desenvolvimento teórico da minha tese. Num trabalho anterior à sua finalização, publiquei na revista do CIEC, Papéis Avulsos, o artigo intitulado "Narrativas Pentecostais: estudo antropológico de grupos negros nos Estados Unidos" (Contins 1992). Nesse texto, analisei o caso norte americano com base em meu trabalho de campo realizado nos Estados Unidos, tomando como foco de descrição e análise as representações do grupo BibleWay, cujos integrantes afirmavam-se como negros e pentecostais. Minha tese era que essas identidades eram reconstruídas e afirmadas dialogicamente, na medida em que exploravam algumas diferenças em relação aos vários grupos que eram classificados como seus opositores em potencial: no plano religioso, os Batistas; no plano étnico, os brancos.

O ponto central da análise era que, ao se diferenciarem étnica e religiosamente de outros grupos, os pentecostais negros americanos criavam uma identidade que se fazia permanentemente ameaçada por esse outro do qual eles queriam obsessivamente diferenciar-se. Durante o processo de conversão essas diferenças emergiam de forma potente. Essas análises 
encontraram respaldo nos debates realizados nos cursos e seminários que frequentei na ECO. Nos anos de 1990 frequentei também um curso sobre religiões no Brasil, conduzido pelo Prof. Rubem César Fernandes no PPGAS do Museu Nacional. Ali também pude trocar ideias relevantes que repercutiram sobre a análise do meu material de pesquisa.

Além dos excelentes cursos oferecidos pelo Programa de Pós-Graduação da ECO/UFRJ, pude também participar ativamente, como pesquisadora, no CIEC (Coordenação Interdisciplinar de Estudos Culturais da ECO/UFRJ), então coordenado pela profa. Heloisa Buarque de Holanda. Além de desenvolver a minha tese, pude também participar de outros projetos relacionados ao tema das relações raciais e étnicas no Brasil. Minha colega de doutorado e também pesquisadora do CIEC, amiga já de muitos anos e professora da ECO, Ilana Strozenberg, foi uma excelente colaboradora nos projetos que viemos a realizar durante aqueles anos. Atualmente continuamos a trabalhar em outros projetos de pesquisa sobre relações étnicas e religiosas e movimentos culturais e sociais, projetos que tiveram origem nas pesquisas realizadas na época do nosso doutorado.

Antes da minha volta definitiva ao Brasil, no ano de 1988, ocorreu uma série de eventos relacionados à celebração dos Cem Anos da Abolição. O CIEC e o Laboratório de Pesquisas Sociais do IFCS/UFRJ participaram ativamente desses eventos. Participei então do chamado "Projeto Abolição", cujo objetivo era levantar os documentos produzidos pelas comemorações da Abolição que pudessem ser usados como pistas para pensar os 100 anos de história dos negros no Brasil. Em primeiro lugar, foi organizada a "Coleção Abolição", que continha um conjunto de documentos raros e significativos para se entender a história contemporânea do negro no Brasil. Os pesquisadores daquele projeto, ao fazerem o levantamento, pensaram justamente em homogeneizar técnicas de entrevistas e histórias de vida, buscando viabilizar e facilitar o trabalho de futuros pesquisadores. Além disso, os debates suscitados por esse material redefiniram as perspectivas de análise do lugar social do negro e das formas de produção de desigualdade e discriminação na sociedade brasileira.

Como já assinalei, esses novos projetos, dos quais participei ao mesmo tempo que escrevia a tese de doutorado, foram suscitados e propiciados pelos posicionamentos assumidos pelos movimentos sociais sobre ação afirmativa. Os debates sobre essa questão explodiram nos anos 1990. Os projetos de que participei no CIEC e no Núcleo da Cor do Laboratório de Pesquisa Social da do IFCS / UFRJ viabilizaram de modo criativo a continuação da minha vida acadêmica e como pesquisadora. 
O Núcleo da Cor, coordenado por Yvonne Maggie, elaborou o projeto "O lugar do social das representações do negro no Brasil", que foi alimentado pelos documentos da "Coleção Abolição". Organizei então o Quase Catálogo 6 (CIEC/ECO/ Museu da Imagem e do SOM, 1997), sob a coordenação de pesquisa de Yvonne Maggie e Ilana Strozenberg, a partir do estudo do material reunido no ano do Centenário da Abolição. Outro produto gerado pelo material desta coleção foi a elaboração de uma pesquisa intitulada "Os movimentos negros no Rio de Janeiro e a questão do Estado", que depois ramificou-se no estudo sobre "O Movimento Negro e a questão da ação afirmativa". Setores destes movimentos defendiam então a tese de que era necessário garantir a realização de políticas públicas, governamentais ou não, que atendessem especificamente e primordialmente à população negra.

Nesses projetos focalizamos as organizações que discutiam a questão racial, pondo em perspectiva os modos como se configuravam as desigualdades existentes entre brancos e negros. Posições contra e a favor das políticas de ação afirmativa, nas suas diversas modalidades---política de cotas, ação compensatória e outras estratégias visando favorecer um maior acesso dos grupos discriminados à educação e ao mercado de trabalho---integravam uma discussão pública naquele momento e da qual os movimentos negros eram interlocutores fundamentais. Esses debates levavam em conta a conjuntura nacional e internacional, a situação da população negra brasileira, os mecanismos de reprodução da discriminação e a problematização da tese da "democracia racial brasileira", e apontavam para as políticas de ação afirmativa como instrumentos de combate à discriminação.

Concentramos o foco da pesquisa nos movimentos negros do Rio de Janeiro entre os anos de 1993 e 1995. Orientei vários bolsistas naqueles anos, tanto no CIEC/ECO quanto no Núcleo da Cor da UFRJ, com apoio da Fundação Ford e do CNPq. Edlaine de Campos Gomes, que mais tarde veio a fazer seu doutorado comigo no Programa de Pós Graduação de Ciências Sociais da UERJ, revelou-se então uma pesquisadora excepcional e, anos mais tarde, viemos a publicar vários artigos em conjunto. José Jairo Vieira e Luiz Carlos Sant'ana auxiliaram-me nas pesquisas sobre ação afirmativa. Luiz Carlos e eu escrevemos em parceria um artigo intitulado "O Movimento Negro e a Questão da Ação Afirmativa" publicado em 1996 pela Revista de Estudos Feministas. Nesse artigo comparamos os debates sobre ações afirmativas nos Estados Unidos e no Brasil. Essa questão veio a ser foco de outras pesquisas quando, em 1999, realizei um pós-doutoramento na Brown University, nos Estados Unidos. 
Os resultados das pesquisas realizadas entre 1993 e 1995 transformaram-se depois no livro intitulado Lideranças Negras, publicado em 2005 pela Editora Aeroplano e com apoio da FAPERJ. Nosso propósito foi ouvir lideranças femininas e masculinas dos movimentos negros no Rio de Janeiro. Conduzimos reuniões com essas lideranças, convidando-as para participar de algumas das atividades promovidas pelo CIEC. Era desejo dessas lideranças, e nosso também, que participassem de discussões dentro do espaço da Universidade e trouxessem seus pontos de vista.

O CIEC da ECO/UFRJ constituía um ambiente interdisciplinar com debates bastante intensos e ricos, com seminários e encontros reunindo pesquisadores nacionais e estrangeiros de áreas diversas, tais como teoria literária, filosofia, história, ciência política, sociologia e antropologia. Era um universo intelectual plural e alegre, onde a circulação de ideias novas era a marca do trabalho das coordenadoras. Havia uma sensibilidade especial para os debates nacionais e internacionais em andamento. Um dos seminários internacionais então organizados, Sinais de Turbulência, reuniu professores universitários e artistas populares, conferências e performances artísticas. Um dos convidados estrangeiros foi James Clifford, historiador americano que então se destacava pelos seus trabalhos sobre história da antropologia. Participaram também daquele seminário o Professor Nelson Vieira do Department of Portuguese and Brazilian Studies da Brown University, que veio a ser meu supervisor de Pós-Doutorado durante os anos de 1999 a 2000; e também o Professor Anani Dzidzienyo, que também integrava os quadros docentes daquele Departamento.

Nos anos subsequentes, estágios de pós-doutoramento tornaram possível o prosseguimento de minha formação, quando nos anos de 1999 a 2000 frequentei, como professora e pesquisadora convidada, o Department of Portuguese and Brazilian Studies da Brown University; em 2011, o Center of Latin American and Caribean Studies da University of New York (NYU); e em 2015, o Institute of Latin American Studies (ILAS) da Columbia University. Não poderia deixar de aqui assinalar que o sistema acadêmico brasileiro, especificamente a UERJ, e as agências de fomento (CNPq, CAPES e FAPERJ) garantiram financeiramente todas essas etapas de minha formação.

Já tendo concluído em 1995 o doutorado na ECO/ UFRJ, fiz concurso em 1996 e fui aprovada como professora adjunta de Antropologia no Departamento de Ciências Sociais do IFCH da UERJ.

Entre os anos de 1999 e 2000, realizei no Department of Portuguese and Brazilian Studies da Brown University, em Providence, Rhodes Island, meu 
primeiro pós-doutoramento. Naquela ocasião, a Universidade me ofereceu, além das oportunidades de acesso a uma excelente biblioteca, a chance de estabelecer contato intelectual com pesquisadores americanos e portugueses dedicados a estudar o mundo luso-brasileiro. Estabeleci então contato também com o Department of African Studies, através do professor Anani Dzidzienyo. Dei prosseguimento, naquela ocasião, à pesquisa de pós-doutoramento sobre ação afirmativa, explorando um quadro comparativo entre os contextos sociais brasileiro e norte-americano. No Brasil, já havia entrevistado alguns alunos universitários que eram bolsistas de cotas em universidades privadas e públicas. Nos Estados Unidos pude entrevistar alunos negros que foram contemplados com políticas de ação afirmativa e que estavam na Brown University, especificamente no Department of African Studies.

Paralelamente à pesquisa de pós-doutoramento, realizei um trabalho de campo completamente novo, junto com José Reginaldo Gonçalves, que também realizava seu pós-doutorado naquela mesma universidade, entre imigrantes açorianos que celebravam a Festa do Divino Espírito Santo na Nova Inglaterra. Providence, capital do Estado de Rhodes Island, é uma cidade repleta de áreas ocupadas tradicionalmente por portugueses oriundos do Arquipélago dos Açores e de Cabo Verde. O acesso a eles era relativamente não era difícil. Naquela ocasião, a circulação de pesquisadores estrangeiros nos Estados Unidos ainda não conhecia as restrições que veio a conhecer depois do trágico evento do 11 de setembro de 2001, ocorrido exatamente um ano após eu concluir esse pós-doutoramento. O projeto de pesquisa que elaboramos junto aos açorianos da Nova Inglaterra foi essencial para que prosseguíssemos posteriormente o trabalho de campo na comunidade de imigrantes açorianos no Rio de Janeiro. Publicamos em parceria alguns artigos sobre a Festa do Divino nos Estados Unidos e no Brasil.

Entre setembro de 2011 e maio de 2012, o Center of Latin American and Caribian Studies ( CLACS) da New York University (NYU) recebeu-me para que eu realizasse meu segundo pós-doutoramento. O universo social e político norte-americano nesta época havia mudado sensivelmente, o que repercutia de modo perceptível no cotidiano da Universidade, notadamente no estrito controle sobre os deslocamentos espaciais de professores e alunos no campus. Durante os meses em que permaneci como pesquisadora e professora visitante explorei amplamente os recursos oferecidos pela NYU, cujo campus fica localizado na área do Greenwich Village. Nesse período pude ter acesso a todo os sistema de bibliotecas da Universidade e a vários departamentos, como o de 
Antropologia, onde pude conhecer alguns pesquisadores, assistir conferências e participar de diversos debates.

O projeto de pós-doutoramento na NYU contou com a supervisão da antropóloga Bambi B. Schieffelin, e teve o suporte intelectual de um produtivo diálogo com professores e alunos. Meu objetivo foi aprofundar as análises que vinha realizando sobre religião e espaço no contexto religioso das grandes cidades. Um dos focos da pesquisa era o processo de transformações no campo religioso e como estas repercutiam no espaço urbano. Minha proposta era desenvolver um trabalho descritivo e analítico sobre a circulação de pessoas, assim como de objetos materiais e seus usos em contextos sociais e rituais, com foco privilegiado nas religiões afro brasileiras.

Além dos contatos no CLACS e no Department of Anthropology da NYU, realizei e também assisti palestras no Brazil Seminars da Columbia University coordenado pelo Prof. Sidney Greenfield, pela Profa. Diana Brown e pela Profa. Vânia Penha Lopes. Participei também de seminários no Religious Studies Center daquela mesma universidade. Na ocasião, dei continuidade aos meus contatos com o Department of Portuguese and Brazilian Studies da Brown University, por intermédio do meu ex-supervisor Prof. Nelson Vieira. Estabeleci contatos também com o Graduate Center da City University of New York (CUNY) através do Professor John Collins.

O terceiro de meus pós-doutoramentos foi um Estágio Sênior no Institute of Latin American Studies (ILAS) da Columbia University, Nova York. Esse estágio me permitiu o acesso a uma nova experiência em relação ao universo acadêmico norte-americano. Estive envolvida, entre os meses de agosto de 2015 e janeiro de 2016, nas atividades do ILAS e do Lehmann Center for Brazilian Studies. Participei de colóquios, seminários e grupos de estudos com professores e alunos da pós-graduação da Columbia. Mantive encontros regulares com os membros docentes da Columbia e com o meu supervisor e diretor do Lehmann Center for Brazilian Studies, Prof. Gustavo Azenha. Pude usufruir das pesquisas em desenvolvimento nesse centro de pesquisa, onde discuti e elaborei um projeto focado na noção de "performance", abordando o campo religioso afro-brasileiro. Em outubro de 2015 apresentei um paper intitulado "The City and the Afro Brazilians Religions" no Seminário do Center for Brazilian Studies da Columbia.

O Brazil Seminars da Columbia University realiza encontros regulares entre pesquisadores de universidades norte-americanas e estrangeiras em várias áreas de estudo, mas com foco no Brasil. Eles foram essenciais para que eu desenvolvesse um novo projeto de pesquisa, desta vez sobre antropólogos 
norte-americanos que tiveram como tema de suas teses o Brasil entre os anos 1950 e 1990. O projeto, ainda em andamento, rendeu, até o presente, a produção de quatro entrevistas e a publicação de uma delas, bem como a organização em um seminário num encontro do Brazilian Studies Association (BRASA).

Ao longo desses anos venho realizando e participando de encontros, seminários e congressos nacionais e internacionais com apoio de diversas agências financiadoras: CAPES, CNPq, FAPERJ e Fundação Ford. Isso me permitiu expor os resultados de minhas pesquisas a outros profissionais no Brasil e no exterior. Devo assinalar também que, desde 1996, participo, como pesquisadora associada, do Programa Avançado de Cultura Contemporânea (PACC) da UFRJ. O PACC, hoje localizado na Faculdade de Letras da UFRJ, constitui um programa de inovação acadêmica que articula pesquisa e extensão em formatos experimentais. No ano de 2004, como pós-doutoranda do PACC, conduzi um projeto em associação com as Profas. Heloisa Buarque de Holanda, Ilana Strozenberg, Beatriz Resende e diversos outros pesquisadores. Nesse ambiente há espaço para a articulação de trabalhos colaborativos em rede com os vários centros acadêmicos da UFRJ e de outras instituições acadêmicas e culturais, assim como com organizações da sociedade civil no país e no exterior. Ali encontrei espaço para discussão dos projetos que eu desenvolvia no Departamento de Antropologia do Instituto de Ciências Sociais da UERJ e no Programa de Pós Graduação em Ciências Sociais dessa mesma Universidade, cujo quadro de docentes e pesquisadores integro desde o ano de 1996.

A formação intelectual e acadêmica de um professor e pesquisador é um processo permanente e, na verdade, interminável. Em todos esses anos pude acumular experiências que, acredito, aperfeiçoaram minha formação inicial, sobretudo no que se refere ao estudo de temas relacionados à antropologia urbana. Se em termos clássicos a antropologia pode ser definida pelo estudo das chamadas sociedades primitivas, fui exposta ao longo de minha carreira ao fato de que, especialmente no Brasil, a disciplina confunde-se com os estudos sobre a própria sociedade brasileira e notadamente com os estudos das religiões, em especial as religiões de matriz africana, o catolicismo popular, o pentecostalismo, além, evidentemente, dos demais temas pertinentes à antropologia urbana.

Como todo profissional de antropologia, devo sublinhar o efeito que teve sobre minha formação cada uma das minhas experiências de campo, mais especificamente aquelas que fundamentaram meus estudos sobre religião e etnicidade. O horizonte temático teve sempre como perfil as concepções de 
pessoa, identidades sociais e individuais e configurações étnicas no contexto das religiões afro-brasileiras, do pentecostalismo e do catolicismo popular.

Desde a obra de autores clássicos, tais como Emile Durkheim, Max Weber e Ernst Troeltsch, o paralelo entre os mundos católico e protestante e suas respectivas relações com a modernidade tem sido um tema recorrente na sociologia e na antropologia da religião. Mudanças recentes nesses universos religiosos, assim como suas adaptações a diferentes contextos sociais e históricos, sugerem que esse tipo de comparação requer uma atualização constante. Tais mudanças nos universos religiosos em contextos urbanos contemporâneos motivaram meus estudos, principalmente as análises comparativas sobre as religiões afro-brasileiras, os pentecostais, o catolicismo popular e os carismáticos católicos.

\section{Atividades Profissionais}

Minha vida profissional teve como horizonte a universidade, seja como professora e orientadora, seja como pesquisadora. Desde a graduação, concentrei meus estudos em antropologia, uma disciplina que se aproximava de minhas expectativas intelectuais e pessoais. A experiência de trabalho de campo, de observação participante e de escrita etnográfica seguramente me atraíam mais do que a chamada metodologia quantitativa. Quando estive na Universidade da Virginia (UVa / EUA), eu já reunia um bom conhecimento sobre o que era realizar um trabalho de campo em antropologia. Naquele contexto, pude colocar em prática e aprofundar minha experiência e meu conhecimento sobre o trabalho de campo e a observação participante.

Minha carreira acadêmica teve início formal na década de 1990, quando fui contratada como "professora colaboradora" de antropologia por meio de um processo de seleção pelo então Departamento de Ciências Sociais do IFCS/UFRJ. Naquela ocasião, eu ainda concluía o doutorado na ECO/UFRJ e foi como professora colaboradora que ministrei alguns cursos de antropologia na graduação da própria Escola de Comunicação da UFRJ, no curso de História do IFCS e na Escola de Educação Física no campus do Fundão. Lembro que fiquei muito empolgada, e ao mesmo tempo assustada, com o desafio de iniciar uma carreira como professora, algo diferente da carreira de pesquisadora que eu vinha realizando desde a graduação.

Mas a universidade se mostrava como o lugar onde eu poderia realizar de modo mais adequado minhas expectativas de trabalho como pesquisadora e professora. Foi naquele momento que a universidade começou a abrir mais 
vagas para professores através de concursos públicos. O trabalho de pesquisa acadêmica, tal como era pensado na década de 1990, era necessariamente associado ao ensino e oferecia boas chances para quem pretendia dedicar-se ao trabalho de pesquisa. A antropologia, do meu ponto de vista, possibilitava também o cultivo de um sentido crítico para os acontecimentos relativos à vida social, política e pessoal daquele momento. No IFCS da UFRJ participei do Núcleo da Cor do Laboratório de Pesquisa Social, inicialmente coordenado pela profa. Yvonne Maggie e pelo prof. Peter Fry e financiado pela Fundação Ford. A ideia do Laboratório era incorporar a prática da pesquisa na formação dos alunos de graduação. Foi no Núcleo da Cor, com a participação de alguns alunos do IFCS, que pude desenvolver meus projetos de pesquisa relacionados ao doutorado e também sobre ação afirmativa e relações raciais no Rio de Janeiro. Alguns desses alunos deram prosseguimento em suas carreiras intelectuais e acadêmicas a pesquisas sobre esses temas.

Depois de ter defendido uma tese de doutorado na ECO/UFRJ em 1996, fiz, naquele mesmo ano, concurso para professora adjunta de antropologia no Departamento de Ciências Sociais / IFCH da UERJ. Imediatamente depois de ter sido aprovada, dei início a minha carreira como professora adjunta. Iniciei ministrando diversas disciplinas, principalmente as de teoria antropológica, que eram obrigatórias, e algumas optativas. Ofereci também disciplinas introdutórias para outros cursos na UERJ, como História, Filosofia e Serviço Social. No Curso de Ciências Sociais, as disciplinas que que ofereci estavam centradas em teoria antropológica, trabalho de campo, antropologia da religião e relações raciais. Meu objetivo como professora foi sempre garantir uma formação básica aos alunos que desejassem não apenas concluir a graduação como bacharel em Ciências Sociais e obter o título para buscar outras carreiras profissionais, mas também àqueles outros alunos que almejassem tornar-se pesquisadores e profissionais de antropologia.

Os cursos na graduação foram fonte decisiva para a continuidade dos meus estudos e pesquisas, uma vez que se constituíam em momentos especiais para revisitar autores clássicos, conhecer autores recentes e discutir temas de pesquisa com os alunos. Foi no contato com os alunos, especialmente os da graduação, que dei continuidade a vários projetos de pesquisa, contando com a participação de bolsistas de Iniciação Científica (PIBIC: Capes, CNPq e UERJ). Minhas experiências de pesquisa eram sempre repensadas quando eu tinha a oportunidade de expô-la aos alunos. Essas trocas impuseram-me um aprendizado constante em minha carreira intelectual e acadêmica. 
Ao longo de meus anos de carreira de magistério posso dizer que tive muitas surpresas agradáveis, obtendo boas experiências com a participação ativa de algumas turmas, tanto na graduação quanto na pós-graduação. Excelentes alunos foram meus bolsistas na graduação e participaram dos meus projetos de pesquisa. Alguns continuaram como orientandos no mestrado e no doutorado. Pude acompanhar a vida acadêmica de alguns deles por um longo tempo. Edlaine de Campos Gomes foi minha primeira orientanda de doutorado no Programa de Pós-Graduação em Ciências Sociais (PPCIS) da UERJ, hoje professora do Curso de Ciências Sociais da UNIRIO e também da Pós-Graduação em Memória Social na mesma instituição. Acompanhei Edlaine desde que foi minha bolsista de pesquisa no CIEC da UFRJ, quando era recém graduada. Posteriormente viemos a trabalhar conjuntamente em projetos de pesquisa e em GTs que propusemos para seminários nacionais e internacionais e publicamos alguns artigos em coautoria. Anderson Soares Gaspar, Andréa Freitas da Silva, Carmem Silvia Moretzshon Rocha, Ionilma Andrade Ferreira e Taimara Brito de Couto foram excelentes alunos e pesquisadores, cuja colaboração foi igualmente decisiva para a realização de meus projetos de pesquisa. Afinal, o trabalho como docente, assim como a produção intelectual do pesquisador, por mais individuais e singulares que possam parecer, dependem de uma extensa rede de relações, a começar com os colegas do seu departamento e com os próprios alunos, viabilizando trocas intelectuais cotidianas que podem por vezes ser decisivas.

Como professora de antropologia do Curso de Ciências Sociais também atuei na área da Extensão da UERJ, onde alguns alunos da graduação vieram a trabalhar sob minha supervisão em projetos do Núcleo de Estudos da Religião (NUER) e da Oficina de Antropologia e Imagem. A Extensão significa uma oportunidade de alargar os estudos acadêmicos para muitos alunos. Os alunos do NUER ganharam um espaço de discussão para se encontrarem tanto com os professores quanto com alunos de outros núcleos, oferecendo um complemento importante na sua formação intelectual e profissional. Outro trabalho que realizei como professora na graduação foi como orientadora de Monografias de final do curso de Ciências Sociais, um complemento obrigatório para os alunos obterem o título de Bacharel em Ciências Sociais. Tive oportunidade de orientar diversas monografias de excelente qualidade.

No final da década de 1990 fui aceita como integrante do corpo docente do Programa de Pós-Graduação em Ciências Sociais (PPCIS) da UERJ. Meu trabalho aprofundou-se quando, como professora da pós-graduação, vi-me diante da difícil tarefa de orientar dissertações e teses. Uma relação de 
orientação é uma relação prolongada e pessoal entre duas pessoas, professor e aluno. É um trabalho muito prazeroso, mas pode trazer uma série de dificuldades específicas, às vezes relacionadas ao próprio trabalho de pesquisa, e também com relação a dificuldades pessoais dos alunos ao conduzirem suas pesquisas e escreverem suas dissertações e teses. É preciso tornar possível que o próprio aluno procure e descubra o que pretende estudar. A relação de orientação caracteriza-se ainda por ser uma espécie de mútuo compromisso que deve levar em conta os interesses e as possibilidades dos alunos assim como dos respectivos orientadores.

Na maioria dos casos de orientação eu tinha bastante interesse nos projetos dos alunos, já que a maioria me procurava em função dos temas relacionados a minha linha de pesquisa na Pós-Graduação e aos artigos que eu havia publicado. Fui procurada, num certo momento dos anos 2000, por diversos alunos ligados aos movimentos negros com projetos sobre relações raciais. Buscavam o PPCIS para realizarem seus mestrados e doutorados. Foi o caso de Amauri Mendes Pereira, que veio da militância nos movimentos negros e me procurou como orientadora para seu doutoramento. Amauri já havia sido entrevistado para meu livro sobre Lideranças Negras (2005). Sua tese, "Para além do racismo e do antirracismo: a produção de uma Cultura de Consciência Negra na sociedade brasileira", trouxe suporte para as discussões que eu já vinha realizando nos cursos da graduação e da pós-graduação.

$\mathrm{Na}$ condição de professora e pesquisadora da graduação e da pósgraduação pude escrever e publicar artigos e livros que foram, em alguns casos, debatidos também com os alunos em sala de aula. Orientei bom número de teses e dissertações excelentes. O talento e capacidade de trabalho de meus alunos permitiram que eu me tornasse uma orientadora bem sucedida. Muitos deles continuaram me procurando mesmo depois da defesa da tese ou dissertação e continuo me relacionando com muitos deles no plano profissional e pessoal.

Ao integrar o quadro de professores do Departamento de Ciências Sociais da UERJ em 1996, encontrei excelentes interlocutores. O mesmo sucedeu quando vim a integrar o PPCIS. Pude então me associar aos colegas da Linha de Pesquisa originalmente intitulada Religião e Movimentos Sociais. Encontrei apoio em uma rede de profissionais, com os quais estabeleci bem sucedidas relações de interlocução intelectual: Cecilia Mariz, Sandra de Sá Carneiro, Patrícia Birman, Rosane Manhães, Clara Mafra e Marcia Leite. Essa Linha de Pesquisa destacou-se no PPCIS pela qualidade de seus pesquisadores. A nossa pós-graduação sempre foi citada e procurada pelos alunos e também por 
pesquisadores da área de estudos sobre religião, em razão de reunir um grupo de pesquisadores bastante produtivos nessa área. Dessa colaboração resultaram projetos, além de livros e artigos que publicamos conjuntamente.

Criei em associação com Cecilia Mariz e Sandra Carneiro, o Núcleo de Estudos da Religião (NUER), que articula pesquisa, ensino e extensão no campo dos estudos da religião. O NUER reúne professores e pesquisadores do Departamento de Ciências Sociais e da Pós Graduação em Ciências Sociais (PPCIS), onde se destacam as pesquisas sobre religião e cidade, religião e etnicidade, além de movimentos sociais, religião e política. Através de um conjunto de atividades tais como organização de acervos, promoção de eventos e convênios, o NUER articulou uma rede de pesquisadores da religião. Participei do Convênio entre a UERJ, representada pelas pesquisadoras Cecília Mariz, e a Dra. Marjo De Theije da Universidade Livre de Amsterdã, Holanda. Essa parceria foi importante para que a UERJ e o NUER realizassem permutas entre alunos da UERJ com alunos da Universidade Livre de Amsterdã.

A implementação do Núcleo de Estudos da Religião possibilitou aos alunos, através de seu acervo, a realização de pesquisas e trabalhos de graduação em Ciências Sociais sobre diversos temas nas áreas de Antropologia da Religião, Sociologia Urbana, entre outras. Possibilitou também a alguns alunos da Linha de Pesquisa "Religião e Movimentos Sociais" tomar conhecimento dos vários temas sobre religião e movimentos sociais que lá estavam, ao realizarem a tarefa de organizar parte desse acervo. Esses alunos participaram da Semana de Extensão, como componentes do NUER, nas atividades da Mostra de Extensão UERJ Sem Muros, contribuindo com apresentações orais, de painel e visualizações sobre suas pesquisas em "folders" a respeito do Núcleo.

Para além desse circuito da Linha de Pesquisa, minhas pesquisas sobre religiões afro-brasileiras e pentecostalismo e catolicismo popular encontraram recepção generosa entre alguns pesquisadores: Cecilia Mariz, Maria das Dores Machado, Peter Fry, Heloisa Buarque de Hollanda, Ilana Strozenberg, Vagner da Silva, Clara Mafra, Sandra Sá Carneiro, Maria Laura Cavalcanti, Edlaine de Campos Gomes, Diana Brown, Vânia Penha-Lopes e Sidney Greenfield. Eles foram, muitas vezes, em momentos difíceis, fontes inestimáveis de apoio profissional e de inspiração intelectual.

Contei também, profissionalmente, com uma rede de profissionais que participaram de seminários nacionais e internacionais e com os quais estabeleci boas relações de interlocução intelectual. Cito, como exemplo, os seminários do Laboratório de Análise Simbólica, do IFCS da UFRJ, organizado por Maria Laura, José Reginaldo Gonçalves e Marco Antônio Teixeira Gonçalves que 
reuniram pesquisadores de diversas partes do país. Pude também apresentar minhas pesquisas, discutir textos e apresentar os resultados de minas pesquisas nos seminários e encontros nacionais e internacionais da BRASA (Brazilian Studies Association), da ABA (Associação Brasileira de Antropologia), da ANPOCS, da RAM (Reunião Antropologia do Mercosul) e da AAA (American Anthropological Association).

\section{Atividades de Pesquisa}

Minha formação, como pude demonstrar, foi fortemente marcada pelas minhas experiências de pesquisa, especificamente o trabalho de campo antropológico. Desde as décadas de 1970 e 1980, ainda como aluna de graduação, realizei pesquisas sobre Umbanda e Candomblé na Baixada Fluminense sob a orientação da Professora Yvonne Maggie. Na Baixada Fluminense daquela época eram numerosos os terreiros de Umbanda e Candomblé e eram em pequeno número as igrejas pentecostais. Os terreiros eram todos eminentemente locais, ou seja, com clientela basicamente do próprio bairro, apesar de receberem eventualmente pessoas de outros locais. Esse contexto vai mudar significativamente nos anos noventa, com uma intensificação das relações dos terreiros com outros bairros da cidade e com o aumento expressivo de igrejas pentecostais.

Analisamos então o lugar desses terreiros para a vida do bairro e produzimos um artigo intitulado "Gueto cultural ou a umbanda como modo de vida" (Maggie; Contins 1980). Realizávamos um trabalho de campo em locais que eram então considerados distantes do centro da cidade. Em geral eram locais menos urbanizados, com ruas sem asfalto e também com poucas possibilidades de transporte para a população local. $\mathrm{O}$ acesso a esses locais da Baixada Fluminense passava necessariamente pela Via Dutra e, em seguida, por ruas estreitas, sem asfaltamento, onde situavam-se os terreiros.

Era frequente a experiência de dormirmos nos locais de pesquisa, já que as sessões de umbanda e candomblé duravam a noite toda, terminando nas primeiras horas da manhã. Percebíamos então que havia uma distância espacial, social e psicológica significativa entre nós e o grupo que estudávamos. Retornar para a cidade do Rio de Janeiro no final dos rituais era muito difícil, as ruas e estradas escuras e nenhuma segurança. Atualmente essas áreas da cidade parecem mais próximas, se as comparamos àqueles anos.

A experiência de campo para nós pesquisadores era muito marcante e toda a interpretação que construímos parecia diminuir e simplificar a realidade 
vivida pelas pessoas. Um ponto decisivo era trabalhar a partir do ponto de vista nativo, ou seja, perceber o significado da religião para suas vidas daquelas mulheres e daqueles homens. Percebemos que, naquele tipo de situação religiosa, a da umbanda principalmente, havia uma relação profundamente estreita e imbricada entre o cotidiano social e o universo religioso. Os terreiros funcionavam como um centro criador de relações simbólicas, étnicas, sociais e econômicas. O bairro onde situava-se o terreiro que estudamos vivia uma situação de relativo isolamento social e espacial e era o centro de onde era gerada grande parte das relações sociais e étnicas, econômicas e simbólicas vividas pelo grupo.

$\mathrm{Na}$ perspectiva que então explorávamos, tratar a umbanda apenas como uma religião significaria deixar de perceber uma dimensão mais ampla desse fenômeno, já que toda a vida social do bairro estava de algum modo relacionada com o que se passava e se formava a partir dos terreiros. Chamamos de "modo de vida da umbanda" esse tipo específico de relação social, econômica e cultural produzida a partir dos terreiros (Maggie; Contins,1980).

Nos anos 1970 e 1980, o trabalho de campo e as análises realizadas em situações sociais específicas, em um único terreiro ou grupo, faziam um contraste significativo com relação às macro-análises realizadas nas décadas anteriores, estudos estes com viés fortemente generalizantes ${ }^{4}$.

Havia, neste momento, um debate com os autores que trataram a umbanda como resultado de um processo de urbanização da cidade. Em As religiões africanas no Brasil (1971) Roger Bastide discute a urbanização das cidades brasileiras e aponta as diferenças entre o "candomblé rural" e a "macumba urbana". Em 1974, Diana Brown discute, na sua tese de doutorado em antropologia, a relação entre religião e política no Brasil urbano. É interessante destacar os trabalhos que relacionavam os estudos da umbanda, da macumba e do candomblé aos contextos urbanos e regionais. São inúmeros esses estudos ${ }^{5}$.

${ }^{4}$ Muitos foram os estudos que focaram suas pesquisas em um único terreiro de umbanda ou candomblé ou produziram densas etnografias, estabelecendo relações pessoais e prolongadas no campo: Beatriz Góis Dantas ( 1982) (Juanna Elbein dos Santos (1986); Yvonne Maggie (2001); Zélia Seiblitz (1979); Anaiza V. Silva (1975); Renato Ortiz (1978); D. dos Santos (1988); Marcio Goldman (1987); Sérgio Ferreti (1985); Patrícia Birman (1995); Paula Monteiro (1983); Barros (1993); Marcia Contins (2009).

${ }^{5}$ Limito-me a apontar alguns clássicos: Rodrigues (1935); Carneiro 1985; Ribeiro 
O livro Guerra de Orixá: um estudo de ritual e conflito inaugura essa mudança no fazer antropológico, um livro escrito, segundo a autora, "em meio a um turbilhão de mudanças no país e na antropologia brasileira" (Maggie, 2001:7). Assim, em termos da antropologia das religiões afro-brasileiras, os enfoques ficaram mais centrados em campos específicos, em estudos de caso, e desta forma rompem com os estudos sobre a busca da origem dessas religiões relacionadas a uma autenticidade africana. O lugar da África estava agora nos próprios terreiros, no presente. O longo trabalho de campo, obrigatório a todo antropólogo que pretende realizar uma boa etnografia, era evidentemente essencial quando iniciei minhas pesquisas de campo.

Uma das pesquisas mais significativas, para mim, foi a que desenvolvi nos anos de 1980 para a minha dissertação de mestrado, intitulada "O Caso da Pomba-Gira: Reflexões sobre crime, possessão e imagem feminina". Dissertação defendida no PPGAS do Museu Nacional, UFRJ, posso afirmar que seus resultados mantêm a sua atualidade, sendo frequentemente citada por outros pesquisadores.

Em 1979, antes desta minha pesquisa de mestrado, Yvonne Maggie, Patrícia Monte-Mór e eu recebemos um financiamento da FUNARTE para discutirmos a relação entre Umbanda e o Estado (Maggie; Contins; Monte- Mór, 1979). A pesquisa focalizou as perseguições policiais aos Terreiros das décadas de 30 a 60. A partir dos jornais da época pudemos ver de que modo essas "crenças" eram tratadas por grupos sociais associados a outras religiões ou que pertencentes a camadas sociais diferentes daquelas a que pertenciam os que costumavam frequentar terreiros. Geralmente as acusações eram no sentido de unir todas essas religiões (Umbanda, Candomblé, Macumba, Quimbanda e também às vezes o Espiritismo) sob o rótulo de "Magia Negra". A "Magia Negra", por seu turno, estaria ligada à criminalidade, "feitiçaria", "violência" etc.

Com o objetivo de perceber a relação entre o Estado e os cultos afrobrasileiros, fizemos um levantamento dos jornais da época, e analisamos a chamada "Coleção Magia Negra", que se encontrava no Museu da Academia de Polícia Civil do Rio de Janeiro. Seus objetos foram apreendidos na repressão aos Terreiros na década de 1930. Visando uma comparação, analisamos também a coleção de objetos religiosos ligados aos Terreiros Xangôs de Alagoas, que se encontram no Museu do Instituto Histórico e Geográfico desse

1952; Ramos 1932; Rio 1906; Bastide 2001; Landes 1967. E alguns estudos mais recentes: Prandi 1991; Carvalho 1984; Segato 1992; Motta 1988; Monteiro 1985; Lima 1977; Fry 1971; Oro 1994; Santos 1995. 
Estado. Neste caso, sua exposição seguia critérios usualmente associados a objetos "museáveis". Eram, na sua maioria, objetos africanos e considerados como dotados de valor histórico. Já na coleção do Museu da Polícia, os objetos estavam curiosamente arranjados na mesma disposição que são classificados e posicionados num terreiro de umbanda ou candomblé. Eram expostos ao lado de outros objetos relacionados a crimes comuns e apreendidos pela Policia Civil do Rio de Janeiro.

O acervo da "Coleção Magia Negra", primeira coleção etnográfica tombada em 1938 pelo IPHAN, depois de quase cem anos sob a tutela da Polícia Civil, veio a ser recentemente transferida para o Museu da República, no Catete. Desde a época em que realizamos essa pesquisa, final da década de 1970, vários grupos religiosos e de movimentos negros tentaram recuperar essa coleção. Esses grupos reivindicavam, além da mudança de nome para "Acervo do Sagrado Afro-Brasileiro", a sua transferência para um Museu de Arte ou um Museu Histórico. A experiência de trabalhar com a "Coleção Magia Negra" foi decisiva na análise que realizei do "Caso da Pomba-Gira", tema de minha dissertação de mestrado.

O "Caso da Pomba Gira", que poderia ter sido rotineiramente noticiado como mais um crime de morte nesta cidade do Rio de Janeiro, veio no entanto a ganhar este título e um amplo espaço no noticiário jornalístico. $\mathrm{O}$ assassinato de um homem (um comerciante de nome Álvaro) na periferia do Rio de Janeiro no ano de 1979, por si só, não mereceria tanto espaço no noticiário policial. Nem mesmo o fato de que a principal acusada fora sua própria esposa. Um outro fato parece ter repercutido mais sensivelmente na consciência coletiva, garantindo assim o interesse despertado pelo acontecimento: segundo os jornais da época, os acusados teriam agido supostamente sob "inspiração sobrenatural". Em outras palavras: uma das principais acusadas, uma médium de nome Celina, habitualmente "recebia" uma entidade de Umbanda, conhecida pelo nome de "Maria Padilha", e teria sido o veículo por meio do qual se realizara aquela inspiração. Narrei esse acontecimento na forma de um "drama social" (Turner,1978), conceito que opera simultaneamente um instrumento de descrição etnográfica e de análise. Diante daquele material, o conceito me pareceu particularmente adequado para o tratamento descritivo e analítico do caso. A partir de um conflito localizado, era possível visualizar as modalidades de mecanismos corretivos acionados para restabelecer algum equilíbrio naquele conjunto de relações. As várias posições explicitadas durante a crise e as fontes de iniciativa para encerrá-las forneciam pistas relevantes para entender o sistema social (Turner, 1978). 
Quando elaborei e concluí minha tese de doutorado, entre os anos de 1991 e 1995, meus interesses já estavam voltados para um estudo comparativo sobre pentecostais negros no Brasil e nos Estados Unidos. O projeto “Tornando-se Pentecostal: um estudo comparativo entre pentecostais negros nos EUA e no Brasil" foi suscitado a partir da experiência de trabalho de campo que realizei no período de 1984 a 1989, quando residi em Charlottesville, Estado da Virginia, nos Estados Unidos. Durante esse tempo, conforme já explicitei, dei início a uma pesquisa junto a um segmento de população negra do sul dos Estados Unidos ou, mais especificamente, com um grupo religioso autodenominado Bible-Way, linha pentecostal de negros que se encontra espalhada também em outros estados norte-americanos. A congregação dos Bible Way tinha a maioria de suas igrejas no Estado da Virginia (Centro e Norte) e em Washington, D.C. Concentrei meus estudos em uma igreja na Virginia, num pequeno distrito no município de Fluvanna, próximo a Charlottesville. Através de contatos com seus integrantes, vim a participar de eventos religiosos em outras igrejas que pertenciam à mesma congregação.

Florescendo em contextos sociais e culturais tão distintos quanto os Estados Unidos e o Brasil (além, obviamente, de outros contextos nacionais), as religiões pentecostais impõem o desafio da comparação. Primeiramente, no caso norteamericano investigado, os pentecostais estão fortemente associados aos negros. Já no contexto brasileiro, a questão da identificação entre cor e religião não aparece tão nitidamente. No entanto, mesmo no caso dos pentecostais negros norte-americanos, onde etnicidade e religião estão de alguma forma articuladas, falar de igrejas pentecostais e neopentecostais enquanto resultantes de uma "cultura negra" requeria alguma cautela. O grupo que estudei pertencia a grupos religiosos cuja especificidade consiste no fato de pertencer a um setor pentecostal de negros. De certo modo, podíamos afirmar que este grupo religioso possuía uma "narrativa étnica". Seus membros criavam e recriavam uma "cultura religiosa", uma linguagem comum, uma maneira de se vestir, uma moral, um relacionamento entre seus membros muito intenso, uma valorização muito forte do aspecto econômico, fosse no plano individual ou coletivo.

Os resultados da pesquisa sugeriam que os "símbolos religiosos" e os "símbolos étnicos" eram tratados como partes de narrativas que estavam constantemente sendo renovadas pelas diferenças. Ou seja: os pentecostais estavam sempre projetando para fora de suas fronteiras essas diferenças, construindo assim uma determinada forma de autoconsciência, um 
interminável processo de construção de subjetividade enquanto negros e enquanto pentecostais.

De volta ao Rio de Janeiro em 1990, e já inscrita no Programa de Pós Graduação em Comunicação e Cultura da ECO/UFRJ em 1991, comecei a pesquisar as igrejas pentecostais no Rio de Janeiro, para que a pesquisa tomasse um rumo comparativo. No caso do estudo no Rio de Janeiro, era impossível a delimitação de uma religião como pertencente a um só grupo étnico ou racial. No entanto, no caso dos grupos pentecostais e neopentecostais, com os quais tive contato, foi possível constatar a forte presença de negros frequentando essas igrejas, tanto na condição de pastores quanto na condição de fiéis. Pesquisei no Rio de Janeiro a Assembleia de Deus, A Igreja de Nova Vida e a Metodista Renovada.

Meu objetivo foi explorar comparativamente a dimensão étnica e religiosa expressa no discurso dos pentecostais negros no Brasil e sua relação de oposição frente às religiões afro-brasileiras. Na tese que escrevi, apontei que o "outro" dos neopentecostais no Brasil eram a Umbanda e o Candomblé. Assim, com base na comparação com os pentecostais norte-americanos, foi possível afirmar que a construção de uma identidade de "pentecostal" e de "negro" era um processo importante também no contexto de algumas igrejas pentecostais no Rio de Janeiro, embora seus "outros" não fossem os mesmos.

Descrevi determinados aspectos do pentecostalismo que emergiram na minha relação com o grupo norte-americano. Foi através do diálogo que mantive com seus integrantes que determinados temas vieram a aparecer, tais como a questão da subjetividade religiosa e étnica. Além disso, eu assinalava que a produção dessa subjetividade se processava através da expulsão das diferenças para fora de suas fronteiras e sua projeção sobre grupos religiosos considerados como "outros". No caso dos pentecostais norte americanos o "outro" eram os batistas; no caso brasileiro, como assinalei, as religiões afrobrasileiras. É sobretudo durante o processo de conversão que essas diferenças emergem com intensidade.

Discuti essas questões exaustivamente em minha tese e posteriormente em vários artigos que vim a publicar. No entanto, meus interesses, em seguida, voltaram-se para um assunto que despertava a atenção naquele momento: as políticas de ações afirmativas no Brasil.

Durante os anos de 1998 e 2000 conduzi o projeto “As Estratégias de Combate à discriminação racial no Brasil: Perspectivas e dilemas da ação afirmativa", com o apoio do CNPQ e da Fundação Ford. A proposta foi suscitada por alguns dos resultados do projeto "Movimentos negros no Rio de 
Janeiro", conduzido entre os anos de 1994 e 1995. Neste projeto foram coletados depoimentos dos principais líderes, homens e mulheres, de movimentos negros no Rio de Janeiro. A partir dessa pesquisa, vim a publicar o livro "Lideranças Negras no Rio de Janeiro" (Contins, 2005). Resultado de uma pesquisa pioneira, a experiência me deu acesso à história dos movimentos negros existentes no Rio de Janeiro na década de 90, através das vozes de algumas de suas principais lideranças. Entre outras questões relevantes relativas à história e atuação dos movimentos negros, destacava-se o debate em torno da validade e pertinência de políticas de ação afirmativa. Este configurou-se como um ponto crucial para a definição das suas perspectivas quanto a estratégias anti-discriminatórias.

A partir de pesquisas que realizei sobre as relações entre discursos étnicos e as ideologias dos programas de "ação afirmativa" ou anti-discriminatórios (Contins 1996; 1998; 1999; 2000a; 2000b), foram suscitados alguns novos problemas, cuja elaboração, acredito, contribuiu para o debate expresso pela crescente literatura produzida sobre o tema no contexto nacional brasileiro da época (Maggie \& Villas Boas, 1998; Contins \& Sant'ana, 1996; Fry,1991; Maggie 1999; Poli 1999).

Meu orientando de doutorado no PPCIS, e um dos entrevistados para o meu livro sobre lideranças negras, Amauri Mendes Pereira, trouxe uma significativa contribuição para a discussão sobre as relações raciais no Brasil e sobre as formas da consciência negra na sociedade brasileira (Pereira, 2006).

$\mathrm{Na}$ medida em que desenvolvi nesses estudos uma perspectiva comparativa, tendo contato com a literatura norte-americana sobre o tema (Taylor,1994; Walters, 1995;Nussbaum, 1999; Bowen \& Bok,1998; Weiss,1997), vim a realizar um trabalho de campo nos Estados Unidos para o meu pósdoutoramento entre 1999 e 2000 na Brown University. Essa comparação veio iluminar, por contraste, o caráter específico que assumiam as discussões desses programas e sua eficácia no contexto da sociedade brasileira.

O projeto de pesquisa que conduzi em meu primeiro pós-doutorado no exterior, no Portuguese and Brazilian Studies da Brown University, intitulava-se “Os Discursos da Ação Afirmativa no Brasil e nos Estados Unidos". A pesquisa buscou acompanhar, primeiramente, algumas iniciativas paradigmáticas de "ação afirmativa" no Rio de Janeiro. O objetivo era buscar uma definição de políticas públicas anti discriminatórias em nosso contexto social, econômico e cultural. Um dos propósitos do projeto era entender a maneira pela qual essas políticas vinham sendo debatidas e implementadas por parte principalmente de segmentos da sociedade civil. Em termos mais amplos, o alvo eram as 
políticas de combate à exclusão social que contemplassem, de forma direta ou indireta, questões relativas às desigualdades raciais vigentes no país e especificamente no Rio de Janeiro. Para isso focalizei diversas instituições de educação universitária, no Rio de Janeiro, onde essa política vinha sendo implantada. Focalizei também o papel da igreja católica e de algumas igrejas protestantes e de grupos evangélicos no processo de combate à desigualdade e à discriminação racial no Rio de Janeiro. Selecionei um grupo de estudantes universitários da PUC/Rio; da UFRJ; e da UERJ. Esse grupo havia passado pelo pré-vestibular para "negros e carentes" e conseguiram ingressar nessas universidades (Contins, 2003).

Minha proposta era tratar as representações da desigualdade embutidas nos discursos étnicos nos Estados Unidos e no Brasil como parte dos processos de construção de autoimagens pessoais e coletivas por parte de coletividades identificadas com alguns programas de ação afirmativa. Esses programas, no caso dos Estados Unidos, eram levados a cabo por parte de agências governamentais em diversos níveis de governo. No caso brasileiro, um conjunto de setores informais implementavam não propriamente programas de ação afirmativa (em seu sentido mais estrito, isto é, nos termos em que esses programas eram definidos no contexto norte-americano), mas voltavam suas preocupações para aquelas populações em condições de desigualdade social e étnica, buscando alterar positivamente a posição destas. Nos Estados Unidos, explorei os programas de "ação afirmativa" desenvolvidos pelas universidades e conduzi diversas entrevistas com bolsistas contemplados por ações afirmativas, estudantes norte-americanos e estrangeiros que estavam estudando na Brown University, principalmente no Departament of African Studies.

Outra experiência de pesquisa que iniciei quando do pós-doutorado na Brown University foi sobre imigrantes açorianos na Nova Inglaterra e a celebração "Festa do Divino Espírito Santo". Através de uma senhora açoriana, que trabalhava na caixa do restaurante da Universidade, tive acesso à comunidade desses imigrantes dedicados à realização anual daquela festa. Foi uma excelente oportunidade para me dedicar, uma vez mais, às comparações entre as sociedades brasileira e norte-americana.

As pesquisas de campo sobre as festas açorianas do divino espírito santo foram realizadas, assim, em dois contextos nacionais de imigração açoriana: Estados Unidos (Nova Inglaterra) entre 1999 e 2000; e Brasil (Rio de Janeiro) entre 2001 e 2004. O trabalho de campo estendeu-se a uma breve permanência, no ano de 2004, na Ilha Terceira, uma das nove ilhas que compõem o 
Arquipélago dos Açores e onde as festas do divino espírito santo são especialmente importantes. No Rio de Janeiro existem diversos bairros e subúrbios da cidade, onde irmandades religiosas dedicadas ao culto do divino espírito santo foram fundadas e são ainda atualmente dirigidas por imigrantes açorianos. Além de realizarmos visitas em quase todas as irmandades no Rio de Janeiro, centramos o trabalho de campo na Irmandade do Catumbi, Zona Norte do Rio de Janeiro. Vários bolsistas de Iniciação Científica e de Mestrado participaram desse projeto. Uma vez mais, as pesquisas receberam apoio financeiro do CNPq, CAPES e FAPERJ.

Descobrimos que no centro desse ciclo de festas estavam algumas categorias que emergiram durante o trabalho de campo tanto na Nova Inglaterra quanto no Rio de Janeiro. Uma delas foi objeto de um artigo que publicamos sobre as noções de "escassez" e a "fartura" (Gonçalves; Contins 2009; 2008). O "tempo das festas" (nos Açores, o "tempo dos impérios") é uma categoria usada pelos açorianos para distinguirem aquele segmento do ciclo anual em que se desenrolam as festas do divino espírito santo. Estas são celebradas anualmente a partir do domingo de Páscoa e durante cinquenta dias até o domingo de Pentecostes. Esse tempo é fortemente demarcado por meio de uma série de alterações espaciais, comportamentais, emocionais, fisiológicas, usos de objetos materiais e que vêm estabelecer simbolicamente uma delicada e progressiva separação em relação a um tempo cotidiano, um tempo profano, voltado para atividades mundanas. As irmandades, tanto nos Estados Unidos quanto no Brasil, trazem simultaneamente aspectos religiosos, folclóricos e culturais fundamentais às formas de autoconsciência dos imigrantes açorianos (Gonçalves; Contins 2016).

Nesse "tempo das festas", os devotos também realizam rezas e missas celebradas na capela da irmandade, sendo a procissão uma parte importante nos rituais do divino. Esse projeto suscitou outras pesquisas, a partir das quais pude desenvolver artigos e projetos comparando procissões nas festas do catolicismo popular e em algumas celebrações umbandistas que também realizam procissões religiosas.

Algumas das teses e dissertações que orientei exploraram essa via etnográfica e analítica. Um dos meus orientandos de mestrado no PPCIS/UERJ, João Alexandre Felix, realizou sua pesquisa de campo sobre a Festa do Divino na Irmandade do Espírito Santo do Encantado, Zona Norte do Rio de Janeiro (Felix, 2015). Anderson Soares Gaspar, outro orientando de mestrando, também participou ativamente da pesquisa sobre as festas do divino espírito santo no Rio de Janeiro e também das pesquisas que realizei 
sobre as procissões religiosas em Centros de Umbanda na área metropolitana do Rio de Janeiro ( Contins, 2013).

Mais recentemente, minhas pesquisas voltaram-se para as diversas formas de enquadramentos religiosos no espaço urbano realizados por diferentes grupos religiosos, especialmente aqueles associados às religiões afro-brasileiras e às igrejas neopentecostais. Venho explorando as relações entre religião e o contexto urbano, analisando o fato de que determinados grupos religiosos distinguem-se pela sua modalidade de inserção no espaço da grande cidade moderna, particularmente na cidade do Rio de Janeiro. Terreiros que antes pareciam muito distantes parecem hoje bem próximos. No trabalho de campo que realizávamos nas décadas de 1970 e 1980 percebíamos uma grande distância entre pesquisadores e pesquisados, uma distância espacial e social. Hoje a visita a algum terreiro da Baixada Fluminense não suscita aquela mesma percepção (Contins, 2013; 2014).

Nessas pesquisas, pude perceber os vínculos de natureza social na experiência desses grupos, sobretudo nos processos de apropriação do espaço da cidade, assim como nos vínculos de natureza cosmológica expressos por categorias mágico-religiosas Desse modo, buscava explorar o ponto de vista nativo para o entendimento de suas experiências (Contins 2005; 2009; 2013; Contins \& Gomes 2007).

No âmbito do Núcleo de Estudos da Religião (NUER) e da Linha de Religião e Movimentos Sociais do Programa de Pós Graduação em Ciências Sociais, dei início a um trabalho de pesquisa sobre mudanças no espaço público da cidade. Os terreiros de umbanda e candomblé tiveram que, a partir de determinado momento, dividir seu espaço com as igrejas pentecostais e neopentecostais. Busquei entender o modo como os grupos religiosos de matriz africana posicionam-se atualmente diante do crescimento dessas outras religiões na área metropolitana da cidade. Grupos religiosos afro-brasileiros assumem projetos culturais em escolas, produzem cursos de religião e desenvolvem eventos com característica de espetáculos em seus terreiros, de modo similar ao que fazem os neopentecostais (Contins; Penha-Lopes, Rocha 2015). Outros de meus orientandos de mestrado, Daniele Ferreira Evangelista e Rodrigo Pereira, desenvolveram em suas dissertações análises importantes sobre experiências de terreiros de candomblé no município do Rio de Janeiro, focalizando aspectos de seus rituais e performances (Evangelista, 2014; Pereira, 2013).

Outra questão importante suscitada pelas pesquisas que realizei e orientei foi a memória dos terreiros de umbanda e candomblé. Pesquisadores e 
entidades oficiais vêm desenvolvendo projetos que buscam grupos associados às religiões afro-brasileiras para realizar o tombamento de terreiros. Através dos registros dos terreiros como "patrimônio imaterial", intensifica-se o diálogo entre pesquisadores e os grupos pesquisados. Para os grupos das religiões afro-brasileiras, a experiência de "virarem patrimônio" já faz parte de seus horizontes. Essa experiência permite que eles escapem das representações folclóricas, a qual os congelariam num certo passado cultural, e que venham a ser reconhecidos como grupos atuantes no presente histórico e em transformação.

Um ponto significativo a assinalar num contraste entre o que pude perceber em minhas pesquisas mais antigas e as pesquisas mais recentes está relacionado à noção de "autenticidade". O processo de registro dos terreiros como "patrimônio imaterial" e a discussão sobre a sua "autenticidade" têm agora a participação dos próprios adeptos dessas religiões. Atualmente é possível encontrar o levantamento de diversos terreiros na região metropolitana do Rio de Janeiro demarcando o local do terreiro, filiação religiosa e entrevistas com mães e pais de santo. Uma de minhas orientandas de doutorado, Letícia Loreto Querétte, pesquisou o Museu da tradição Xambá no terreiro de Santa Bárbara em Pernambuco, analisando a organização de um Memorial dedicado à mãe de santo fundadora e seus objetos (Querétte, 2014).

As mais antigas igrejas evangélicas, localizadas nas grandes cidades, já atuavam em locais onde havia predominância da Igreja Católica e de terreiros de Candomblé e Umbanda (como na Baixada Fluminense) e privilegiavam atividades religiosas voltadas à congregação e à população local. Mas as igrejas neopentecostais apresentam características distintas. Estas são igrejas basicamente organizadas para receber um grande público, diferentemente das igrejas pentecostais mais tradicionais, como a Assembleia de Deus. Minha orientanda de doutorado, Edlaine de Campos Gomes, analisou em sua tese de doutorado o debate sobre a autenticidade na Igreja Universal do Reino de Deus (Gomes, 2011). Além de disporem de um público fixo, investem em uma clientela difusa e móvel. Sua arquitetura distingue-se das construções das pequenas igrejas de bairro, que ainda existiam nas décadas de 1970 e começo de 1980. Uma das características importantes está em sua localização, geralmente no entroncamento de grandes avenidas, próximas a estações do metrô e expostas assim aos permanentes deslocamentos da população.

Muitos orientandos contribuíram para as minhas pesquisas mais recentes sobre performance e religião, desenvolvendo projetos sobre dança e gênero na Igreja Neopentecostal (Ricco, 2015; Couto; 2019). Victor Hugo de Oliveira, meu 
orientando de doutorado, pesquisou a Dança de São Gonçalo de Amarante, discutindo ritual e performance (Oliveira, 2016). Carmem Silva M. Rocha, também minha orientanda de doutorado, discutiu a relação entre sonoridades, performance e imagens nos rituais de Umbanda em Corumbá (Rocha, 2013). Dulcídio Cossa, orientando de mestrado, contribuiu para a discussão sobre ritual e performance, descrevendo uma cerimônia sobre uma bebida sagrada em Moçambique (Cossa, 2017) . Esse conjunto de estudos, todos realizados no âmbito do PPCIS/ICS/UERJ e do NUER (Núcleo de Estudos da Religião), tornou mais complexas as discussões que venho realizando sobre performance e religião.

No espaço da cidade desenha-se um contexto de pluralidade em que a prática religiosa tem sido mais transitiva e a procura por novas experiências ultrapassa seus espaços territoriais originais. Um dos pontos relevantes que percebemos a partir desta nova configuração religiosa no espaço urbano, foi o lugar e a visibilidade das religiões afro brasileiras. Em pesquisas realizadas recentemente (Contins 2013,2014) observei algumas iniciativas ligadas às casas de candomblé voltadas para o grande público, através de uma forte aproximação com a mídia, com programas em rádios locais e na televisão. Destacam-se também a produção de cursos sobre história da África em alguns barracões de candomblé na Baixada Fluminense, cursos de línguas africanas, produção, divulgação de CDs e vídeos sobre seus rituais, focalizando diferentes entidades do candomblé. A tese da minha orientanda de doutorado, Daniela Calvo, trata exatamente desses cursos que são oferecidos em um terreiro de Candomblé e sobre tratamentos terapêuticos para a cura de doenças (Calvo, 2019). Glícia Caldas, Yalorixá do Ylê Ayaba Afefé-Afeiyka (“Casa da Rainha da Ventania") no Rio de Janeiro e historiadora, foi uma importante interlocutora nas pesquisas mais recentes que realizei.

O que se observa hoje são diferentes casas de candomblé e umbanda no Rio de Janeiro que privilegiam a relação com o mercado, com a universidade e com os movimentos negros. A participação e o reconhecimento de pesquisadores nesses terreiros contribuem para a sua visibilidade. Trata-se de uma espécie de diálogo que se estabelece com o grande público e que não fica mais restrito às pequenas casas ou terreiros situados em algum distante bairro na Baixada Fluminense ou noutra área periférica da cidade, contexto que conheci nos anos setenta.

Nas pesquisas que conduzi, destaco o exemplo de diferentes grupos afro brasileiros que inovaram seus rituais. Focalizei alguns grupos no subúrbio e na Zona Oeste do Rio de Janeiro, que construíram terreiros maiores ou os 
modificaram com o objetivo de se aproximarem de um público mais amplo: um barracão de Candomblé localizado em Vila Valqueire; um outro em Irajá; e um terceiro em Anchieta. Analisei, com base na discussão da literatura sobre ritual e performance, a importância desses barracões para a comunidade local e para além dos limites desses bairros. Comparando os dois primeiros terreiros, que possuem uma importância local bastante forte (durante os seus rituais há uma enorme troca e participação de diversos terreiros da região), com o barracão do bairro de Anchieta, verifiquei que neste último destacava-se a forma de "espetáculo" assumida por seus rituais. Os dois primeiros eram menores e com um público oriundo de bairros próximos. Já as festas no barracão de Anchieta para as entidades do candomblé eram realizadas em um grande salão com a participação de uma grande audiência de fora do bairro. Os rituais são filmados e gravados em CDs que depois eram vendidos no Mercadão de Madureira.

O pai de santo deste terreiro tem um programa semanal na radio e se apresenta em programas de televisão. Ao mesmo tempo, percebemos que os rituais internos (só para as pessoas do próprio candomblé) têm importância fundamental para a continuidade desse barracão. $\mathrm{O}$ ritual como espetáculo, no entanto, é parte relevante da relação com o grande público. A sua forma arquitetônica é significativa na relação que se estabelece entre as religiões afrobrasileiras e as outras religiões. Sua forma monumental aproxima-se da arquitetura típica das igrejas neopentecostais.

A casa onde funciona o terreiro em Anchieta assemelha-se a um templo pentecostal com três andares. No primeiro andar fica o salão onde o ritual para as entidades é realizado. Nesse salão comparecem para ver o espetáculo pessoas de diversos bairros da cidade e também da Baixada Fluminense. Um membro do terreiro filma o espetáculo e depois este $C D$ é colocado à venda em lojas do Mercadão de Madureira. Ao lado da casa há uma entrada para a parte de baixo do terreiro, onde se realizam as obrigações de santo, sendo também o local onde os membros do terreiro vestem-se e preparam-se para os rituais. Esse espaço constitui uma espécie de "bastidores" da casa, onde somente as pessoas consideradas de dentro do terreiro podem permanecer. Os convidados assistem tudo no salão, que tem a forma de um teatro, com bancos ao redor do palco.

O tema da autenticidade, assunto discutido por vários antropólogos sobre a "africanidade" dos terreiros baianos, é neste caso construído a partir de imagens que são produzidas e distribuídas nos mercados pelo próprio grupo, que assume integralmente sua autoria. $\mathrm{O}$ próprio pai de santo e alguns 
membros do terreiro elaboram um ritual específico para uma plateia, ensaia os participantes, filma em $\mathrm{CD}$ e distribui no mercado.

Minha tese é que, na medida em que esse acesso ao sagrado se dá no universo de uma grande metrópole moderna (Rio de Janeiro), essas práticas tendem a assumir, para além de sua forma ritual, o caráter de "espetáculos", em razão mesmo de atender uma clientela que se caracteriza por seu elevado índice demográfico e uma relação eminentemente funcional com a religião.

Os resultados dessas pesquisas indicam alguns aspectos gerais e que merecem destaque. O movimento permanente de incorporação e diferenciação de estilos de vida e visões de mundo distintas, característico da grande cidade (Simmel 1971; 1987; Velho 1980; 1994; 2010), é um aspecto crucial. A vida cosmopolita oferece possibilidades e alternativas ao indivíduo através de redes de pertencimento, sistemas de troca, mediações e trocas contínuas inscritas no contexto da cidade. O fluxo entre fronteiras religiosas, étnicas e reinterpretações das orientações institucionais admitem novas representações em termos de categorias espaciais e sociais.

Neste balanço de minha produção intelectual, penso que posso assinalar minha contribuição à constituição de um determinado campo de pesquisas. Neste, é possível entender as formas contemporâneas da experiência religiosa em sua densa e complexa relação com as grandes metrópoles e suas transformações. Estas transformações, cabe assinalar, atingem tanto os objetos da pesquisa quanto os seus pesquisadores.

Neste texto, pretendi apontar não somente para algumas transformações do campo religioso, mas da própria antropologia, a qual tem igualmente repercutido essas transformações em suas formas de descrição e análise. Assim, a natureza das relações entre sujeito e objeto de pesquisa veio a ser desestabilizada, expondo-se as fronteiras móveis e instáveis entre uma e outra categoria. Um sujeito que pode se tornar objeto. E vice-versa. Uma lição antropológica clássica, mas que tem se imposto com muita força nas últimas décadas, assumindo notáveis dimensões socioculturais e políticas.

\section{Referências}

BASTIDE, Roger.

As religiões africanas no Brasil. São Paulo, Pioneira, 2v. 1971

BASTIDE, Roger.

0 Candomblé da Bahia.; rito nagô. São Paulo,

Companhia das Letras. 2001
BIRMAN, Patrícia.

Males e malefícios no discurso neopentecostal. In: 0 malà brasileira. Rio de Janeiro, Eduerj. p. 62-80. 1997. 
BROWN, Diana.

Umbanda: religion and politics in urban Brazil. Tese ( Doutorado em Antropologia) - Columbia University, New York. 1974.

CALV0, Daniela.

“Cuidar da saúde com a força vital da natureza. Tratamentos terapêuticos no candomblé". Tese de Doutorado/ PPCIS/UERJ.2019.

CARNEIRO, Édison.

Candomblés da Bahia. Rio de Janeiro, Civilização Brasileira.1978.

CONTINS, Marcia.

Quase catalogo: Visões da Abolição 1988. Rio de Janeiro, CIEC, ECO, UFRJ, Museu da Imagem e do Som. 1997.

CONTINS, Marcia.

“Estratégias de combate à discriminação racial no contexto da educação universitária no Rio de Janeiro". In: Ângela Paive (org), Ação afirmativa na universidade: reflexões sobre experiências concretas Brasil-Estados Unidos. Rio de Janeiro : Ed. PUC-Rio; Desiderata. pp. 103-148. 2003.

CONTINS, Marcia.

Lideranças Negras. Rio de Janeiro, Aeroplano/Faperj. 2005.

CONTINS, Marcia.

“0 caso da Pomba - Gira: reflexões sobre crime, possessão e imagem feminina". In: Edlaine Gomes (org). Dinâmicas contemporâneas do fenômeno religioso na sociedade brasileira. São Paulo, Idéias e Letras. 2009.

CONTINS, Marcia; GOMES, Edlaine de Campos.

“Os percursos da fé: uma análise comparativa sobre as apropriações religiosas do espaço urbano entre pentecostais e carismáticos". PONTOURBE - Revista eletrônica do Núcleo de Antropologia Urbana da USP, n.1. http://www.n-a-u.org/revistadonau.html. 2007.

CONTINS, Marcia.

"Autenticidade e Edificações Religiosas: comparando carismáticos católicos e neopentecostais". Revista Anthropológicas. Recife, UFP, 19 (1):169-200. 2008.
CONTINS, Marcia.

0 movimento negro e a questão da ação afirmativa.Cob. de Luiz Carlos Sant'ana. In: Estudos Feministas, v.4,n.l. Rio,IFCS/UFRJ PPCIS/UERJ.p.209-220. 1996.

CONTINS, Marcia.

Tornando-se pentecostal: um estudo comparativo sobre pentecostais negros nos EUA e no Brasil. Tese de doutorado. Prog.de Pós-Graduação em Comunicação e Cultura. ECO/UFRJ. 1995.

CONTINS, Marcia.

Perpectivas e dilemas da "Ação Afirmativa": As estratégias de combate à discriminação racial no contexto da educação universitária no Rio de Janeiro. Pesquisa/UERJ/FORD/UFRJ. 1998.

CONTINS, Marcia.

Espaço, Religião e Etnicidade: um estudo comparativo sobre as representações do Espírito Santo no Catolicismo Popular e no Pentecostalismo In: Religião e Espaço Público; Org Patricia Birman. Rio de Janeiro, Attar Editorial/CNPq/PRONEX. Pp 221-234. 2003.

CONTINS, Marcia.

A circulação social e ritual de objetos materiais em dois contextos religiosos: as procissões de São Miguel Arcanjo e do Divino Espírito Santo no Rio de Janeiro. In: Geraldo Ramos Pontes Jr.; Myrian Sepúlvedra dos Santos; Rogério Ferreira de Souza; Victos Hugo Adler Pereira. (Org.). Cultura, Memória e Poder: diálogos interdisciplinares. 1ed.Rio de Janeiro: EdUERJ, 2013, v. 1, p. 93-1. 2013.

CONTINS, Marcia.

Ritual e Performance no espaço urbano: 0 caso das Religiões Afro-brasileiras. In: Marcia Contins; Vania Penha-Lopes, Carmem Silvia M. Rocha. (Org.). RELIGIOSIDADE E PERFORMANCE: DIÁLOGOS CONTEMPORANEOS. 1ed.Rio de Janeiro: Mauad/ Faperj, 2015, v. 1, p. 65-84.

CONTINS, Marcia, GONÇALVES, Jose Reginaldo.

Religião, Folclore e a Ilusão do Arcaismo: As festas do Divino Espírito Santo. In: Edlaine de Campos Gomes; Paola Lins de Oliveira. (Org.). Olhares sobre o Patrimônio Religioso. Rio de Janeiro. 1ed.Rio de Janeiro: Editora Mar de 
Ideias (Coleção Editorial Tramas de Ideias, v.5), 2016, v. 3, p. 29-56.

GONÇALVES, José Reginaldo, CONTINS, Marcia.

Entre o Divino e os Homens: A arte nas festas do Divino Espírito Santo. Horizontes Antropológicos, v. 14, p. 67-94, 2008. Versão impressa ISSN 0104-7183

CONTINS, Marcia; PENHA-LOPES, Vania; ROCHA, Carmem (Orgs)

Religiosidade e performance: diálogos contemporâneos. 1. ed. Rio de Janeiro: Mauad/ Faperj, 2015. v. 1. 204p.

CONTINS, Marcia.

The City and the African-Brazilian Religions. Vibrant (Florianópolis), v. 11, p. 246-266, 2014.

CONTINS, Marcia.

As Religiões Afro Brasileiras e a Cidade. Revista Z Cultural (UFRJ), v. 2, p. 1-15, 2013.

CONTINS, Marcia; GOLDMAN, Marcia.

0 caso da Pomba-Gira: uma análise do jogo discursivo entre umbanda e violência. Rio de Janeiro, Religião \& Sociedade. 1983

COSSA, Dulcídio Manuel Albuquerque.

"MHAMBA YA UKANYI" o ritual de UKANYI: uma tradição da modernidade. 2017.

COUT0, Taimara Pereira do.

A "Mulher V": uma análise sobre a construção da da "virtuosidade feminina" na Igreja Universal do Reino de Deus.Dissertação de Mestrado. 2019.

DANTAS, Beatriz Góis.

Repensando a pureza nagô. Religião e Sociedade. São Paulo, Cortez/ Tempo e Presença, n.8. 1982.

EVANGELISTA, Daniele Ferreira.

A pessoa é para o que nasce: Um estudo sobre mudança de status e relações de poder no candomblé. Dissertação de mestrado PPCIS/ UERJ. 2014.

FELIX, João Alexandre.

Os vitelos do Divino Espírito Santos. In: Religiosidade e performance: diálogos contemporâneos . Org. Contins,M; PenhaLopes, V e Rocha, C S M. Rio de Janeiro, MauadX, FAPERJ.2015

\section{FERRETITI, Sérgio Figueiredo}

Repensando o sincretismo: estudo sobre a Casa das Minas. São Paulo, Edusp/Fapema. 1985.

FRY, Peter.

"Politicamente correto num lugar,incorreto noutro? (relações raciais no Brasil, nos EUA, em Moçambique e no Zimbábue)". in: Estudos Afro-Asiáticos, Rio de Janeiro,n.21,dez.1991.

FRY, Peter.

Duas respostas à aflição: umbanda e pentecostalismo. I: Debate e Crítica(6):74-95

\section{FRY, PETER.}

Politicamente correto num lugar, incorreto noutro?. Relações raciais no Brsil, nos EUA, em Moçambique e no Zimbábue. In: Rio de Janeiro, Estudos Afro-Asiáticos, n. 21, dez.1991.

FRY, PETER \& MAGGIE, Yvonne.

0 debate que não houve: a reserva de vagas para negros nas universidades brasileiras. Revista Eletrônica Enfoque, pp93-117. Rio de Janeiro, Renovar. 2002

GEERTZ, Clifford. 1988.

Works and lives: the anthropologist as author. Stanford Univ. Press.

GEERTZ, Clifford. 2000.

Available light: anthropological reflections on philosophical topics. Princeton: Princeton University Press.

GOMES, Edlaine de C.

A era das catedrais da IURD: a autenticidade em exibição. Rio de Janeiro, Garamond, 2011.

GOLDMAN, Marcio.

A possessão e a construção social da pessoa no candomblé.Rio de Janeiro, PPGAS; Museu Nacional; UFRJ. 1984.

HASEMBAL, C.A.

Discriminação e Desigualdades raciais no Brasil. Rio de Janeiro,Graal, 1979. 
HIRSCHMAN, Albert 0.

A retória da Intransigência: perversidade, futilidade, ameaça. São Paulo, Companhia das Letras. 1992.

MAGGIE, Yvonne.

Guerra de orixá: um estudo de ritual e conflito. Rio, Zahar. 2001.

MAGGIE, Yvonne \& CONTINS, Marcia.

"Gueto cultural ou a umbanda como modo de vida: notas sobre uma experiência de campo na Baixada Fluminense". Gilberto Velho (org). 0 desafio da cidade. Rio, Campus. 1980.

MAGGIE, Yvonne

Medo de feitiço: relações entre magia e poder no Brasil. Rio de Janeiro, Arquivo Nacional 1992.

MAGGIE, Yvonne; Villas Boas, Glácia Kruse \& outros.

Cor e educação: políticas alternativas de combate à exclusão. Rio, IFCS/UFRJ, Laboratório de Pesquisa Social. 1998.

MAGNANI, JG.

“De perto e de dentro: notas para uma etnografia urbana". Revista Brasileira de Ciências Sociais, 17 (49) . pp: 11-29. 2003

MARIZ, Cecília Loreto \& MACHADO, Maria das Dores Campos.

"Mudanças recentes no campo religioso brasileiro". Revista Antropolítica, UFF, 5: 2143. 1998.

\section{MAUSS, Marcel}

Ensaio sobre a dádiva. Forma e razão da troca nas sociedades arcáicas. In: Sociologia e Antropologia. São Paulo, EDUSP. p37-59 .1974

ORO, Ari (org).

As religiões afro-brasileiras do Rio Grande do Sul. Porto Alegre, Ed. da UFRGS. 1994.

ORTIZ, Renato. A morte branca do feiticeiro negro: umbanda, integração de uma religião numa sociedade de classes. Petrópolis, Vozes. 1978.

PEREIRA, Rodrigo.

No reino das duas senhoras: a análise do ritual do axexê e da reestruturação do Terreirro Ilê Omô
Oyá. Dissertação de mestrado PPCIS/UERJ. 2013.

PEREIRA, Amauri Mendes

"Para além do racismo e do anti-racismo:a produçao de uma Cultura de Consciencia Negra na sociedade brasileira". Tese de Doutorado/ PPCIS/UERJ 2006.

QUERÉTTE, Leticia Loreto.

A tradição Xambá: um estudo antropológico sobre o Museu Severina Paraiso da Silva. Tese de Doutorado/ PPCIS/UERJ 2014.

RICCO, Ana Letícia Aires Ribeiro.

Dança e religiao: Um olhar sobre a dança como performance no Protestantismo. Dissertação de Mestrado/ PPCIS/UERJ/2015.

ROCHA, Carmem Silvia Moretzsohn.

Apurando os sentidos: Sonoridades, performance e imagens nos rituais de Umbanda em Corumbá. Tese de Doutorado. 2013.

RODRIGUES, Nina.

0 animismo fetichista dos negros baianos. Rio de Janeiro, Civilização Brasileira.

SAPIR, Edward.

Cultura autêntica e espúria. In: Sociologia e Antropologia. V. 2 (4): 35-60. Rio de Janeiro, IFCS/PPGSA/UFRJ. 2012SIMMEL, G.. On individuality and social forms. Chicago; Londres, Univ. of Chicago Press. 1971.

SILVA, Anaíza Virgulino da.

0 tambor das flores: uma análise da Federação Espírita Umbandista e dos cultos afrobrasileiros do Pará (1965-1975). Universidade de Campinas. 1976.

SIMMEL,G.

"A metropole e a vida mental". In: Gilberto Velho (org.) 0 fenômeno urbano. Rio de Janeiro, Zahar. 1987.

\section{SIMMEL,G.}

On individuality and social forms. Chicago; Londres, Univ. of Chicago press. 1971.

TRILLING, Lionel.

"Sincerity and authenticity" .Cambridge, Harvard Univ. press. 1973 
TURNER, Victor.

From ritual to Theatre: The human seriousness of play. New York, PAJ Publications.1980.

TURNER, Victor.

The anthropology of performance. New York, Paj Publication 1987.

VELHO, Gilberto. 0 desafio da cidade: Novas perspectivas da antropologia brasileira. Rio de Janeiro, Campus. 1980.

VELHO, Gilberto.

Projeto e metamorfose. Antropologia das sociedades complexas. Rio, Zahar. 1994.
VELH0, Gilberto.

Metrópole, cosmopolitismo e mediação. Horizontes Antropológicos, 33: 15-24 . 2010.

WAGNER, Roy.

The invention of culture. Chicago, The University of Chicago Press. 1981.

WALTERS, $R$.

0 Princípio da Ação Afirmativa e o Progresso Racial nos EUA. In: Estudos Afro-Asiáticos ,Rio de Janeiro, n. 28, out.1995. 